\title{
Article \\ Cold Atmospheric Pressure Plasma Treatment of Maize Grains-Induction of Growth, Enzyme Activities and Heat Shock Proteins
}

\author{
L'udmila Holubová 1,*(D), Renáta Švubová ${ }^{2, *(D)}$, L'udmila Slováková ${ }^{2}$, Boris Bokor ${ }^{2,3}$, \\ Valéria Chobotová Kročková ${ }^{2}$, Ján Renčko ${ }^{2}$, Filip Uhrin ${ }^{1}$, Veronika Medvecká 4 (D), Anna Zahoranová 4 (D) \\ and Eliška Gálová ${ }^{1}$
}

Citation: Holubová, L'.; Švubová, R.; Slováková, L'.; Bokor, B.; Chobotová Kročková, V.; Renčko, J.; Uhrin, F.; Medvecká, V.; Zahoranová, A.; Gálová, E. Cold Atmospheric Pressure Plasma Treatment of Maize Grains-Induction of Growth, Enzyme Activities and Heat Shock Proteins. Int. J. Mol. Sci. 2021, 22, 8509. https://doi.org/10.3390/ ijms22168509

Academic Editor: Ricardo Molina

Received: 9 July 2021

Accepted: 4 August 2021

Published: 7 August 2021

Publisher's Note: MDPI stays neutra with regard to jurisdictional claims in published maps and institutional affiliations.

Copyright: (c) 2021 by the authors. Licensee MDPI, Basel, Switzerland. This article is an open access article distributed under the terms and conditions of the Creative Commons Attribution (CC BY) license (https:/ / creativecommons.org/licenses/by/ $4.0 /)$.
1 Department of Genetics, Faculty of Natural Sciences, Comenius University in Bratislava, Mlynská dolina, Ilkovičova 6, 84215 Bratislava, Slovakia; f.uhrin@gmail.com (F.U.); eliska.galova@uniba.sk (E.G.)

2 Department of Plant Physiology, Faculty of Natural Sciences, Comenius University in Bratislava, Mlynská dolina, Ilkovičova 6, 84215 Bratislava, Slovakia; ludmila.slovakova@uniba.sk (L'.S.); boris.bokor@gmail.com (B.B.); krockovavaleria@gmail.com (V.C.K.); rencko.jan@gmail.com (J.R.)

3 Comenius University Science Park, Comenius University in Bratislava, 84104 Bratislava, Slovakia

4 Department of Experimental Physics, Faculty of Mathematics, Physics and Informatics, Comenius University in Bratislava, Mlynská dolina F1, 84248 Bratislava, Slovakia; medvecka3@uniba.sk (V.M.); zahoranova1@uniba.sk (A.Z.)

* Correspondence: ludka.holub@gmail.com (L'.H.); renata.svubova@uniba.sk (R.Š.)

\begin{abstract}
Zea mays L. is one of the most produced crops, and there are still parts of the world where maize is the basic staple food. To improve agriculture, mankind always looks for new, better methods of growing crops, especially in the current changing climatic conditions. Cold atmospheric pressure plasma (CAPP) has already showed its potential to enhance the culturing of crops, but it still needs more research for safe implementation into agriculture. In this work, it was shown that short CAPP treatment of maize grains had a positive effect on the vitality of grains and young seedlings, which may be connected to stimulation of antioxidant and lytic enzyme activities by short CAPP treatment. However, the prolonged treatment had a negative impact on the germination, growth, and production indexes. CAPP treatment caused the increased expression of genes for heat shock proteins HSP101 and HSP70 in the first two days after sowing. Using comet assay it was observed that shorter treatment times (30-120 s) did not cause DNA damage. Surface diagnostics of plasma-treated grains showed that plasma increases the hydrophilicity of the surface but does not damage the chemical bonds on the surface.
\end{abstract}

Keywords: CAPP; DCSBD; DNA damage; germination; glucanase; heat shock proteins; non-thermal plasma; maize; protease

\section{Introduction}

Maize (Zea mays L.) is one of the oldest crops that humanity has domesticated. It belongs to the most produced cereal crops, together with wheat and rice, and its production is estimated to grow steadily in the next decade. It is an important staple food in many parts of the world, and maize for human consumption is estimated to rise, especially in Sub-Saharan Africa. Besides food production for humans, there is a strong demand for bioethanol and animal feed and other maize products such as corn starch or syrup [1]. It is thus essential to ensure effective and sustainable methods of growing maize, where new technologies like plasma agriculture could have a place.

Plasma is ionized gas containing various reactive, neutral, and charged particles. Non-thermal, low-temperature or "cold plasma" means that heavy particles-ions and neutrals-remain near room temperature, and electrons reach high temperature due to their high mobility [2-4]. Therefore, a remarkable characteristic of cold plasma is the low 
gas temperature, but also the presence of reactive components, UV radiation (mainly in nitrogen or $\mathrm{N}_{2}$-containing gases such as air), and high-energy electrons. Cold atmospheric pressure plasma (CAPP) is very suitable for practical use. Its production does not require a low-pressure vacuum device. The exact composition of non-thermal plasma (NTP) depends on the type of plasma source and the working gas used. For example, CAPP generated in different ratios of $\mathrm{O}_{2}: \mathrm{N}_{2}$ by Diffuse Coplanar Surface Barrier Discharge (DCSBD) analyzed by Fourier Transform Infrared spectroscopy (FTIR) and optical emission spectroscopy showed the presence of oxygen and nitrogen species $\left(\mathrm{NO}, \mathrm{NO}_{2}, \mathrm{~N}_{2} \mathrm{O}, \mathrm{N}_{2} \mathrm{O}_{5}, \mathrm{HNO}_{3}\right.$ ) and excited molecules $\left(\mathrm{NO}^{*}\right.$ or $\mathrm{N}_{2}{ }^{*}, \mathrm{~N}_{2}{ }^{+*}$ ) responsible for producing radiation in the UV region by deexcitation. Additionally, a relatively high amount of ozone is produced in an oxygen-rich mixture [5].

The use of non-thermal plasma in agriculture is a promising concept since many studies state that plasma treatment of seeds can enhance germination and growth parameters of seedlings [6-9] and sterilize the surface of seeds [10-12], which is vital for cereal crops, since diseases may be detrimental to the economy and threaten food supplies [13]. It was observed that the enhancement of germination is related to the changes on the seed surface after the NTP treatment [14-16]. Reactive particles in NTP interact with the surface, usually making it more hydrophilic $[17,18]$. NTP does not cause any surface damage; only with a significantly prolonged treatment time fine cracks can appear, which depends on the properties of the surface. The reactive plasma species interact with the surface, penetrate it and induce secondary elementary reactions $[6,19]$. These changes can result in quicker water absorption during imbibition and quicker induction of germination $[14-16,20]$. Besides the faster water uptake, the activity of enzymes, which mobilize the seed reserves, is essential. The increase in activity of proteases and glucanases, which was observed in seedlings from plasma-treated seeds, is also connected to the enhancement of germination and growth $[20,21]$.

There are many reactive oxygen and nitrogen species (RONS) in the NTP. On the one hand, RONS contained in NTP (e.g., $\mathrm{O}_{2}{ }^{-}, \mathrm{OH}, \mathrm{NO}$ ) may play a role in the breaking of dormancy and enhancing seeds' germination [22]. On the other hand, however, NTP treatment of seeds or seedlings may cause oxidative or nitrosative stress. Indeed, Billah et al. [23] observed increased amounts of $\mathrm{H}_{2} \mathrm{O}_{2}$ in roots and leaves of Vigna mungo L., especially for longer exposure times, after the treatment of seeds with NTP. Some authors noticed an increase in the activity of antioxidant enzymes, such as superoxide dismutase, catalase, or peroxidases $[22,24,25]$. However, the results regarding the activity of antioxidant enzymes are a bit ambiguous. For example, Henselová et al. [26] did not observe significant changes in the activity of these enzymes in maize seedlings from NTP-treated grains, and Tong et al. [27] noticed the increase in the activity only for catalase in one experimental group, and even a decline in the activity of superoxide dismutase (SOD) in several groups.

Differences in the effects of NTP treatment between publications may be caused by the variety of plasma devices. For example, DCSBD plasma source is CAPP, specified by the high surface and volume power density (appr. $2.4 \mathrm{~W} \cdot \mathrm{cm}^{-2}, 80 \mathrm{~W} \cdot \mathrm{cm}^{-3}$, resp.), which leads to the short treatment times (up to 20-50 s), suitable for practical applications [28]. On the other hand, Puač et al. [29] had to use treatment times in a range of tens of minutes with their low-pressure plasma generated by a radio-frequency capacitively coupled plasma reactor at lower powers (50-200 W). To compare the effect of NTP on different species, the plasma source should be the same. However, pre-sowing plasma treatment is also speciesspecific. For example, Štěpánová et al. [30] compared the CAPP treatment of pepper and cucumber seeds and found that both species have different optimal treatment times. This suggests that it is important to study the effect of NTP treatment on various plant species.

In plants, there are several general defenses against various stresses. Besides antioxidants, heat shock proteins (HSPs) are among the first to respond. As molecular chaperones, their role is to refold, disaggregate, or send to degradation misfolded proteins and prevent aggregation. The activity of HSPs and heat shock factors (HSFs) is also important in priming or acquired tolerance to stress [31,32]. For example, Lämke et al. [33] stated that HSFA2 (Heat shock factor A2) is essential for sustained thermotolerance in Arabidopsis. A 
similar result was observed by Charng et al. [34]. HSFA4A (Heat shock factor A4A) was found to be important for salt and oxidative stress tolerance in Arabidopsis [35]. HSP70s are the most abundant HSPs in cells, and besides physiological functions, they are necessary under various stresses. The increase of HSP70 protein was observed, for example, in Lemna minor as a response to exposure to heavy metals [36].

This paper studied the influence of CAPP treatment of maize grains on the germination and growth parameters and activities of lytic and antioxidant enzymes. We verified physical and chemical changes on the maize grains surface due to plasma treatment in different working gases. We also monitored the DNA damage caused by this treatment and looked at the expression of some heat shock protein genes to find if they are involved in the response of maize to the CAPP treatment.

\section{Results and Discussion}

\subsection{ATR-FTIR}

In Attenuated Total Reflectance-Fourier Transform Infrared spectroscopy (ATR-FTIR) spectra acquired from the surface of maize grains, we can identify the characteristic chemical groups attributed to lipids, carbohydrates, and proteins. In $3000-2800 \mathrm{~cm}^{-1}$ the significant peaks attributed to symmetric and asymmetric stretching of methyl and methylene $\left(\mathrm{CH}_{3}\right.$ and $\left.\mathrm{CH}_{2}\right)$ group can be visible, originating primarily from lipids [37,38]. Additionally, the deformation vibrations of $\mathrm{C}-\mathrm{H}$ bonds occur at $1460-1400,1370$, and $1240 \mathrm{~cm}^{-1}$ in "the fingerprint" region [39]. Carbohydrates are presented by a typical glycosidic bond at around $1020 \mathrm{~cm}^{-1}$ and other bonds in region $1200-800 \mathrm{~cm}^{-1}$ [40]. Three distinct groups represent proteins: amide I (stretching vibration of $\mathrm{C}=\mathrm{O}$ ) at $1640 \mathrm{~cm}^{-1}$, amide II (stretching of $\mathrm{C}-\mathrm{N}$ and deformation of $\mathrm{N}-\mathrm{H}$ ) in $1550-1520 \mathrm{~cm}^{-1}$ and amide III (vibrations of $\mathrm{N}-\mathrm{H}$, $\mathrm{C}-\mathrm{N}, \mathrm{C}-\mathrm{C}$ bonds) at about $1240 \mathrm{~cm}^{-1}$. In addition, the weak band of amide A (N-H stretching vibration) can be found in a spectra of proteins at about $3200 \mathrm{~cm}^{-1}$, but it is overlapped by a strong, wide band of $\mathrm{OH}$ stretching in $3600-3000 \mathrm{~cm}^{-1}$ [41].

The changes due to the plasma treatment of samples can be noticed in two regions; $3000-2800 \mathrm{~cm}^{-1}$, where we can observe the decrease of $\mathrm{C}-\mathrm{H}$ bonds, and in interval $1800-1550 \mathrm{~cm}^{-1}$, in which the carbonyl $(\mathrm{C}=\mathrm{O})$ group is typical. This effect is considerable on samples treated by air and oxygen plasma. A decrease in chemical groups typical for lipids indicate the activation of the maize surface by oxidation and removal of the top lipid layer (Figure 1).

\subsection{Wettability}

The water contact angle (WCA) measured on untreated samples was $107.9 \pm 4.1^{\circ}$, thus, the surface is considered hydrophobic (WCA $>90^{\circ}$ ). After plasma treatment, the contact angle significantly decreased even at a short exposure time. After $30 \mathrm{~s}$ of treatment, the value of WCA was reduced approximately by $50 \%$ in all working gases. The value below $<5^{\circ}$ corresponds to the complete spreading out of the droplets, which was reached in air (A) and oxygen $(\mathrm{O})$ plasma after $300 \mathrm{~s}$ of treatment. In nitrogen $(\mathrm{N})$, the contact angles were higher after a longer treatment time (180 s and $300 \mathrm{~s}$ ) (Figure 2). This effect is related to the different mechanism of plasma action on grains surface due to the different active particles generated in nitrogen (mainly reactive nitrogen species), where the absence of oxygen leads to low ability to remove lipids from the surface observed by ATR-FTIR analysis. 


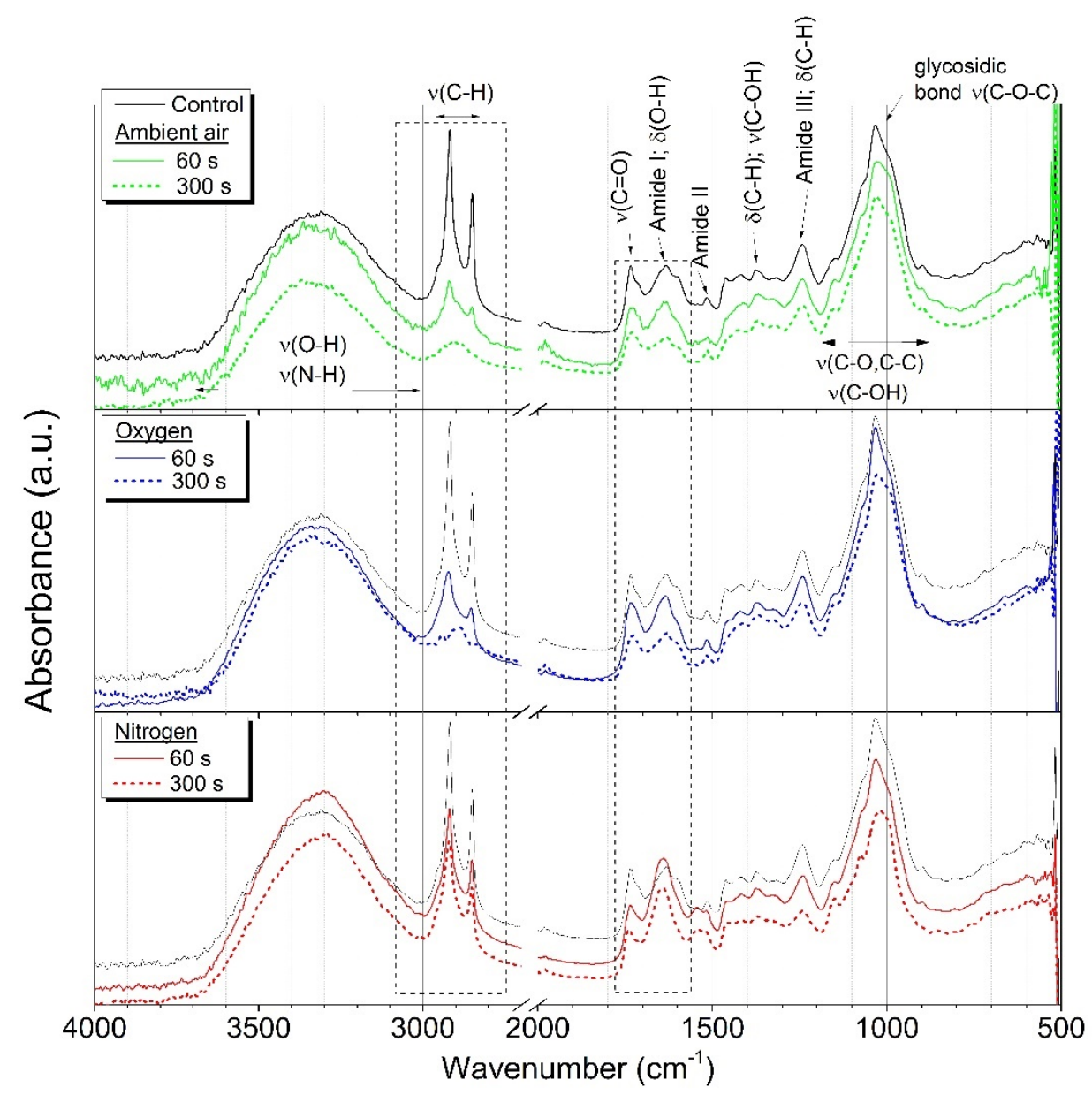

Figure 1. Attenuated Total Reflectance-Fourier Transform Infrared spectroscopy (ATR-FTIR) spectra of maize grains untreated and after plasma treatment in ambient air, oxygen and nitrogen, treatment time $60 \mathrm{~s}, 300 \mathrm{~s}$, at input power $400 \mathrm{~W}$.

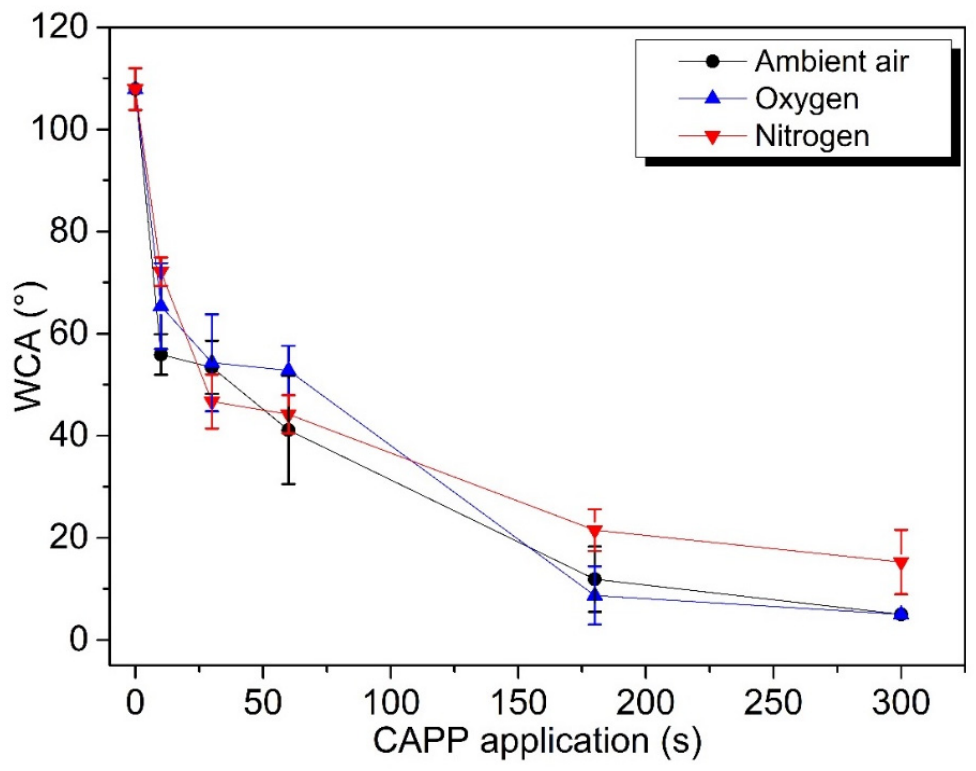

Figure 2. Effect of plasma exposure time on the water contact angle (WCA) measured on maize grains, samples treated by ambient air, oxygen, and nitrogen Diffuse Coplanar Surface Barrier Discharge (DCSBD) plasma at atmospheric pressure, the input power was $400 \mathrm{~W}$. Values are the mean $\pm \mathrm{SD}$, $n=10$. 


\subsection{Physiological and Biochemical Parameters}

Seed germination is the first and very critical period in the life cycle of each plant. The seeds must absorb water to activate their metabolism, and this hydration kinetics takes place in three phases $[42,43]$. First, seeds absorb water through physical mechanisms and this phase is independent of the metabolic activity of the seeds so that it occurs equally well in living and dead seeds. However, dead or damaged seeds can absorb more water than live seeds because the turgor pressure in live seeds acts against hydration [44]. Imbibition of seeds initiates a sequence of events that results in the mobilization of reserves to the embryo, elongation and division of cells and subsequent protrusion of the radicle through surrounding layers [45]. It is known that plasma treatment can affect seed germination at the initial imbibition stage [46]. Our results show that the application of CAPP had a positive effect on imbibition in all studied variants (except the A30 variant).

Statistically, significantly more water was taken up by maize grains treated with CAPP which was generated in an oxygen atmosphere for 30,180 and 300 s, and in CAPP which was generated in ambient air for 60 and 300 seconds (Figure 3A). Many authors claim that plasma application can partially disrupt/modify seed/grain coating layers. Thus reactive particles can penetrate deeper and directly interact with storage tissues or with the embryo [6,47]. Low-temperature plasma significantly modifies the surface of seeds and grains, thereby altering their affinity for water [48,49]. Zahoranová et al. [50] found out that application of CAPP for 10 seconds on maize grains (cv. Ronaldinio) resulted in the reduction of the water contact angle by $50 \%$. They did not notice any damage to the grain surface even after prolonged exposure to CAPP, but they observed higher grain hydrophilicity and higher water uptake. We suppose that it may be partly caused by the surface properties of maize grains, especially by their hardness and the gentle diffusion character of DCSBD plasma. These findings agree with our results, and this effect can be explained by the increasing concentration of polar groups containing oxygen and nitrogen on the surface of treated maize grains. Our results are consistent with the observations of other authors $[17,51]$.

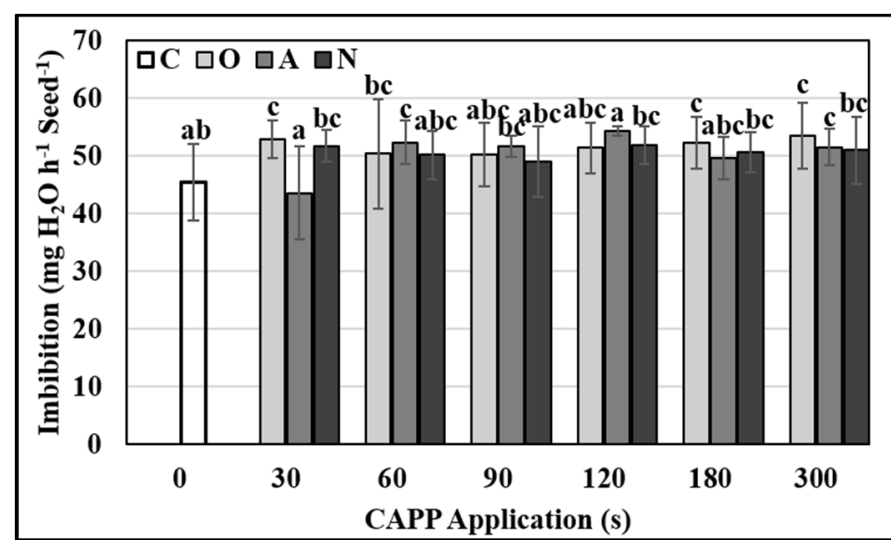

(A)

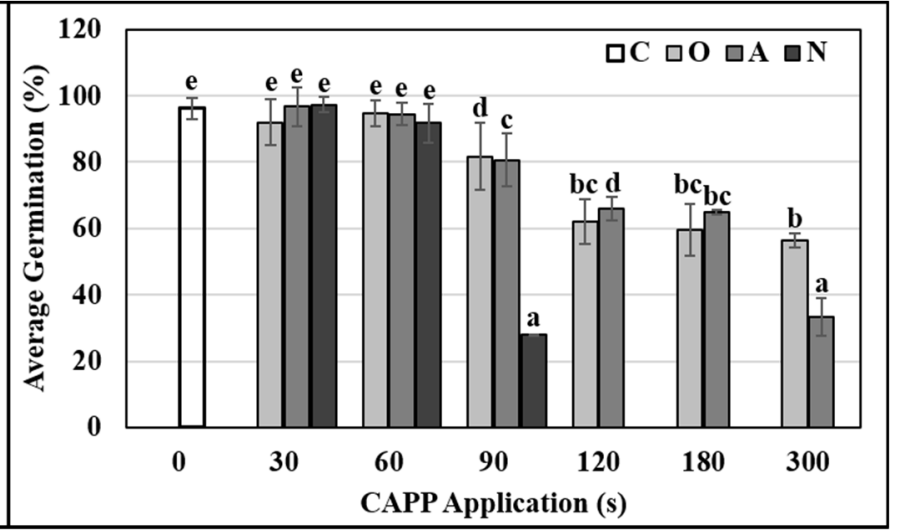

(B)

Figure 3. Imbibition (A) and germination (B) (\%) of maize grains after Cold Atmospheric Pressure Plasma (CAPP) treatment. Variants: C-control/untreated maize grains; O30-O300: maize grains treated with plasma generated in an oxygen atmosphere for 30, 60, 90, 120, 180 or 300 s; A30-A300: maize grains treated with plasma generated in ambient air for 30, 60, 90, 120, 180 or 300 s; N30-N300: maize grains treated with plasma generated in a nitrogen atmosphere for 30, 60, 90, 120, 180 or $300 \mathrm{~s}$. Different letters indicate significant difference at $p$-value $<0.05$, bars are means of ten experimental runs (one run represents 50 grains per variant, $n=500) \pm$ SD to LSD ANOVA test.

As the maize grains (cv. Ronaldinio) used in this study had approximately $95 \%$ germination, we did not notice an increase in the germination percentage due to CAPP application. However, the germination rate at the low exposure times (in all used working gases) remained statistically comparable to the untreated control. On the other hand, the 
quicker germination of maize grains after exposure to the magnetic field might be due to increased activities of germination related enzymes, fast hydration of membranes and greater molecular mobility of water [52]. Despite the increased imbibition, we observed a significant adverse effect on the germination of maize grains with prolonged exposure to CAPP ( 90 or more seconds in all used working gases). Doses of 120 or more seconds of CAPP generated in a nitrogen atmosphere completely inhibited germination (Figure 3B). Using FTIR Spectroscopy, it was confirmed that the generation of plasma in a nitrogen and ambient air atmosphere produces ultraviolet (UV) radiation [5], which is harmful in high doses (according to the WHO). Ultraviolet radiation is a part of the light spectrum and penetrates relatively deep through the seed coat. Nitrogen plasma produces more intensive UV radiation than ambient air plasma, which could be the reason of germination inhibition of grains treated by nitrogen plasma at $120 \mathrm{~s}$ or more. High doses of CAPP (90 or more seconds in all used working gases) also had a negative impact on growth and production indexes. The grains had a reduced germination potential (\%), germination index $(\%)$ and vitality/vigor index (\%). Young seedlings also had a negatively affected vitality/vigor index (\%) and were generally shorter (seedling length index in \%). Our results are also supported by the findings of Shao et al. [53], who stated that extended plasma application on maize grains decreased germination and vigor of young plants. In general, we can say that a shorter duration of CAPP ( 30 and $60 \mathrm{~s}$ ) had a positive effect on the vitality of grains and young seedlings, which were longer compared to the untreated control (Table 1). Our statement is also confirmed by the results of Feng et al. [54] for the application of helium plasma, and Karmakar et al. [55] for the application of argon and oxygen plasma to maize grains. In the case of most variants with the lowest application time (from 30 to $60 \mathrm{~s}$ ), we did not notice statistically significant differences in germination and growth of seedlings compared to the control. In O30 and N30 variants, the grain vitality index significantly increased. Prolonged exposure time caused stress and negatively influenced germination and growth parameters of maize.

To find out the influence of plasma on biochemical mechanisms of plant germination, we also monitored the total soluble protein content and activities of lytic and antioxidant enzymes. The concentration of total soluble protein and the activity of lytic and antioxidant enzymes in three-day-old maize seedlings were affected by CAPP. In the case of the concentration of total soluble proteins (SP), we recorded an increase in all variants, and the trend changed depending on the working gas in which the CAPP was generated. Plasma generated in an atmosphere of oxygen and nitrogen caused an increase (statistically significant for O30, 60, 120, 180 and 300) in the concentration of total SP with increasing time of exposure to CAPP, compared to the untreated control. In the case of CAPP generated in ambient air, the concentration of total SP increased linearly until the treatment time of $120 \mathrm{~s}$. After that there was a decrease, but even in 180 and $300 \mathrm{~s}$ treatment, the concentration of total SP was significantly higher (about two times higher) than in the untreated control (Figure 4). The increased concentration of proteins in the early stages of development after plasma treatment can be explained in two ways. Mobilization of storage proteins occurs in the early stages of germination. These storage proteins are mobilized by proteases and endopeptidases (especially cysteine proteases) and hydrolyzed to amino acids (AA), and subsequently deaminated to carboxylic acids (CA). Before proteins are hydrolyzed into AA and CA, the concentration of soluble proteins increases. These are then used as a source of energy in germination, growth, and development processes. The most studied was Papain-like cysteine protease which begins to be expressed in aleurone layer cells after imbibition [57]. The other possible explanation is the activation of the defense mechanisms of the young, germinated plant because in addition to mobilizing storage proteins, these cysteine proteases are known to play an important role in programmed cell death and also in the response of seedlings to biotic or abiotic stress factors [58]. In these processes, different stress proteins are synthesized. Chaperones maintain the correct conformation of proteins; ubiquitin designates damaged proteins, which are subsequently degraded by proteases. 
Table 1. Impact of different Cold Atmospheric Pressure Plasma (CAPP) applications on growth parameters of Zea mays L. cv. Ronaldinio. Grains were pre-treated with different variants of CAPP (C—control/untreated maize grains; O30-O300: grains treated with plasma generated in an oxygen atmosphere for 30, 60, 90, 120, 180 or 300 s; A30-A300: maize grains treated with plasma generated in ambient air for 30, 60, 90, 120, 180 or 300 s; N30-N300: maize grains treated with plasma generated in a nitrogen atmosphere for 30 and $60 \mathrm{~s}$ ). Values in table represent means of at least 4 independent experiments (one experiment represents 10-20 measurement data) \pm SD according to LSD ANOVA test. Different letters indicate significant difference at $p<0.05$. Indexes were calculated according to Abdul-Baki and Anderson [56].

\begin{tabular}{|c|c|c|c|c|c|}
\hline $\begin{array}{c}\text { CAPP } \\
\text { Application (s) }\end{array}$ & $\begin{array}{l}\text { Germination } \\
\text { Potential (\%) }\end{array}$ & $\begin{array}{l}\text { Germination } \\
\text { Index (\%) }\end{array}$ & $\begin{array}{c}\text { Grain Vitality } \\
\text { Index (\%) }\end{array}$ & $\begin{array}{c}\text { Seedling Vitality } \\
\text { Index (\%) }\end{array}$ & $\begin{array}{c}\text { Seedling Length } \\
\text { Index }(\%)\end{array}$ \\
\hline $\mathrm{C}(0)$ & $96.9 \pm 3.52 \mathrm{f}$ & $10.84 \pm 1.64 \mathrm{jk}$ & $158.1 \pm 23.9 \mathrm{fgh}$ & $0.34 \pm 0.08 \mathrm{ef}$ & $172.8 \pm 20.5$ ef \\
\hline $\mathrm{O} 30$ & $94.0 \pm 8.48 \mathrm{f}$ & $8.66 \pm 1.88 \mathrm{ghi}$ & $205.4 \pm 18.5 \mathrm{i}$ & $0.34 \pm 0.09$ ef & $189.5 \pm 41.2 \mathrm{f}$ \\
\hline O60 & $92.3 \pm 6.32 \mathrm{f}$ & $11.66 \pm 0.38 \mathrm{k}$ & $124.4 \pm 29.7$ cde & $0.29 \pm 0.11 \mathrm{def}$ & $154.2 \pm 34.9 \mathrm{def}$ \\
\hline O90 & $78.7 \pm 12.3$ ef & $7.00 \pm 0.05$ efgh & $152.9 \pm 24.0$ efgh & $0.27 \pm 0.04$ cde & $136.0 \pm 1.0$ cde \\
\hline O120 & $64.2 \pm 5.83 \mathrm{de}$ & $7.56 \pm 0.79 \mathrm{fgh}$ & $92.3 \pm 4.7 \mathrm{bc}$ & $0.23 \pm 0.01$ bcde & $107.3 \pm 11.3 \mathrm{bc}$ \\
\hline O180 & $59.5 \pm 7.77$ bcde & $7.00 \pm 0.35$ efgh & $78.5 \pm 26.8 b$ & $0.14 \pm 0.03 \mathrm{ab}$ & $98.1 \pm 33.5 \mathrm{bc}$ \\
\hline O300 & $58.0 \pm 2.82$ bcde & $4.83 \pm 0.23$ bcde & $73.9 \pm 21.2 \mathrm{ab}$ & $0.08 \pm 0.02 \mathrm{a}$ & $90.8 \pm 23.6 \mathrm{bc}$ \\
\hline A30 & $95.0 \pm 7.07 \mathrm{f}$ & $8.66 \pm 0.47 \mathrm{ghi}$ & 189. $6 \pm 14.1 \mathrm{hi}$ & $0.29 \pm 0.06 \mathrm{def}$ & $163.8 \pm 17.3$ ef \\
\hline A60 & $93.0 \pm 4.35 \mathrm{f}$ & $10.75 \pm 1.75 \mathrm{ijk}$ & $145.6 \pm 28.8$ ef & $0.31 \pm 0.09 \mathrm{def}$ & $182.1 \pm 36.0 \mathrm{f}$ \\
\hline A90 & $67.0 \pm 4.24 \mathrm{abc}$ & $6.16 \pm 1.17$ cdef & $139.1 \pm 8.8 \mathrm{def}$ & $0.29 \pm 0.02 \mathrm{def}$ & $113.3 \pm 3.7 \mathrm{bcd}$ \\
\hline A120 & $68.0 \pm 2.82$ cde & $5.50 \pm 0.71 \mathrm{abcd}$ & $96.6 \pm 4.1 \mathrm{bcd}$ & $0.22 \pm 0.01 \mathrm{bcd}$ & $96.3 \pm 5.1 \mathrm{bc}$ \\
\hline A180 & $56.7 \pm 14.52 \mathrm{abcd}$ & $4.40 \pm 1.12 \mathrm{abc}$ & $94.6 \pm 2.3 b c$ & $0.21 \pm 0.07 \mathrm{bcd}$ & $87.0 \pm 12.1 \mathrm{ab}$ \\
\hline A300 & $36.2 \pm 5.44 \mathrm{ab}$ & $2.91 \pm 0.87 \mathrm{ab}$ & $38.0 \pm 5.2 \mathrm{a}$ & $0.17 \pm 0.01 \mathrm{abc}$ & $49.3 \pm 6.9 \mathrm{a}$ \\
\hline N30 & $98.0 \pm 2.82 \mathrm{f}$ & $9.00 \pm 1.41$ hij & $188.0 \pm 5.4$ ghi & $0.35 \pm 0.05$ ef & $172.7 \pm 27.1$ ef \\
\hline N60 & $87.2 \pm 6.31 \mathrm{f}$ & $6.66 \pm 1.52 \mathrm{defg}$ & $148.4 \pm 28.3 \mathrm{efg}$ & $0.39 \pm 0.11 \mathrm{f}$ & $182.5 \pm 30.2 \mathrm{f}$ \\
\hline N90 & $28.0 \pm 0.50 \mathrm{a}$ & $2.33 \pm 0.23 \mathrm{a}$ & - & - & - \\
\hline N120 & - & - & - & - & - \\
\hline N180 & - & - & - & - & - \\
\hline N300 & - & - & - & - & - \\
\hline
\end{tabular}

Proteases are known to control signaling pathways in imbibed grains and plants. They play an important role, especially during germination, in the mobilization of storage proteins, such as free amino acids that can be used to build proteins and enzymes essential for embryo development [59]. However, these signaling pathways can also be disrupted by the action of highly reactive species that arise during NTP generation, which may explain the change in total soluble protein content in the germinated seedlings. The work of Henselová et al. [26] pointed to similar findings.

Concentrations of total SP in individual variants correlated with protease activity Figure 5A). This means that in the case of the variant with high protease activity, the concentration of total SP decreased. We explain this by the fact that the high protease activity rapidly cleaved SP into amino acids and peptides, which cannot be detected by the methodology according to Bradford [60]. We assumed that the higher activity in three-day-old seedlings was due to proteases that should mobilize storage proteins at this stage of development, assemble proteins into the correct conformation and, in addition, break down damaged proteins. Glucanase activity increased rapidly only in the variants where the maize grains were treated for 30 and $60 \mathrm{~s}$ in CAPP generated in an oxygen atmosphere. In other variants, the activity of this enzyme was comparable to the untreated control (Figure 5B). During germination and early growth of seedlings, storage proteins are degraded and mobilized by proteases, with degradation of both subunits being similar but faster for $\beta$-conglycinin [61]. The storage proteins are cleaved into amino acids 
which, upon degradation to pyruvate, $\alpha$-ketoglutarate, succinyl-CoA, fumarate and/or oxaloacetate, enter the Krebs cycle. Several authors agree that an appropriately chosen plasma application dose can have a positive effect on the activity of lytic enzymes and thus on the mobilization of storage substances in seeds and grains. Zhang et al. [25] reported that argon plasma positively affected soybean seed germination as well as the growth and development of young seedlings by regulating the level of demethylation of genes associated with energy metabolism. Acceleration of the germination process by positively influencing the activity of lytic enzymes (proteases, glucanases, amylases) is also presented in the works by Sadhu et al. [62] for mung beans, Švubová et al. [19] for pea seeds, Švubová et al. [20] for soybean, and Pet'ková et al. [21] for barley grains. The effective mobilization of storage substances and the increase of the soluble sugar and protein content in oilseed rape seedlings are documented by Ling et al. [63].

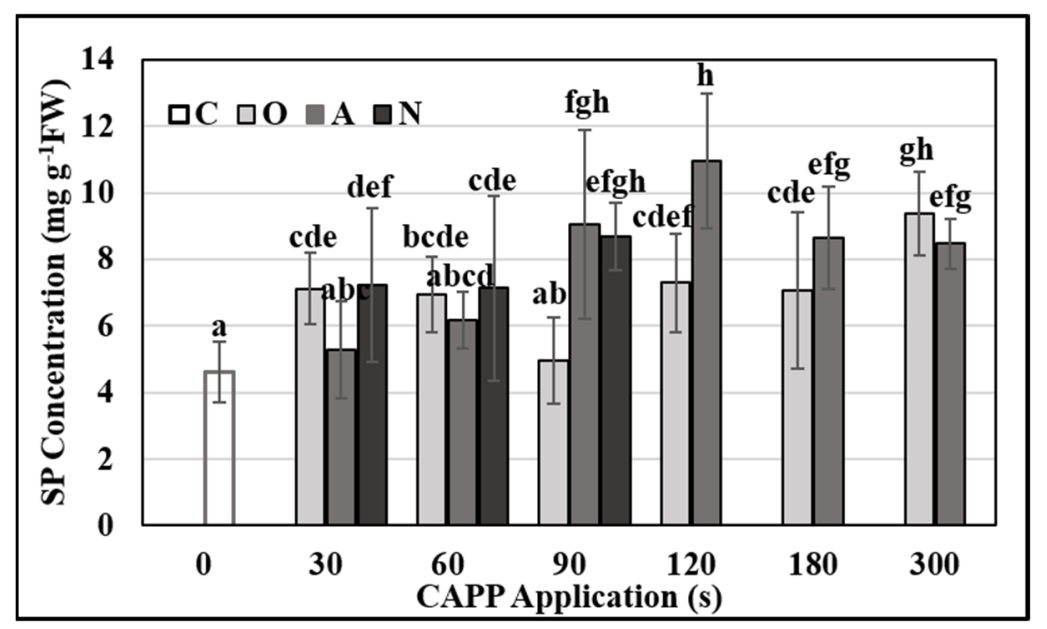

Figure 4. Total soluble protein (SP) concentration in 3-day-old maize seedlings after Cold Atmospheric Pressure Plasma (CAPP) treatment of grains. Variants: C—control/untreated maize grains; O30-O300: maize grains treated with plasma generated in an oxygen atmosphere for 30, 60, 90, 120, 180 or 300 s; A30-A300: maize grains treated with plasma generated in ambient air for 30, 60, 90, 120, 180 or 300 s; N30-N300: maize grains treated with plasma generated in a nitrogen atmosphere for 30, $60,90,120,180$ or $300 \mathrm{~s}$. In the case of N120-300 variants, the maize grains did not germinate, so they are not shown in the graph. Different letters indicate significant difference at $p$-value $<0.05$, bars are means of ten experimental runs (one run represents 50 grains per variant; three $1.5 \mathrm{~g}$ mixed samples were analyzed per one experimental run and each variant for soluble protein concentration) \pm SD according to LSD ANOVA test.

Low-temperature plasma generated in ambient air usually consists of reactive oxygen and nitrogen species such as $\mathrm{NO}_{2}, \mathrm{~N}_{2} \mathrm{O}, \mathrm{NO}, \mathrm{O}_{3}, \mathrm{HNO}_{3}, \mathrm{HNO}_{2}, \mathrm{CO}_{2}, \mathrm{OH}^{-}, \mathrm{O}_{2}{ }^{-},{ }^{1} \mathrm{O}_{2}$. One of the possible mechanisms for plasma-induced stimulation of seed/grain germination is that the biochemical processes inside the seeds are activated by RONS [5]. Reactive oxygen and nitrogen species formed during plasma generation can act as signaling molecules and initiate a cascade of germination processes [64]. Emerging oxidative stress can lead to irreversible damage of lipids, proteins, membranes and DNA [65-67], but the extent of damage depends on the capacity of their antioxidant system. The removal of reactive oxygen species (ROS) from cells is ensured by various antioxidant mechanisms, including the enzymes SOD and peroxidases (POX). The superoxide anion is efficiently removed from the cells by the enzyme superoxide dismutase by dismutation to hydrogen peroxide. Guaiacol peroxidase (G-POX) prefers aromatic compounds such as guaiacol and pyrogallol as electron donors [68]. Because G-POX is active intracellularly (in the cytosol and vacuole), as well as extracellularly (in the cell wall), it is considered a key enzyme in the efficient removal of $\mathrm{H}_{2} \mathrm{O}_{2}$ [69]. 
After evaluating the activity of antioxidant enzymes, we can state that CAPP treatment did not increase oxidative stress in three-day-old maize seedlings. The activities of SOD in the treated variants were comparable to the untreated control (Figure 6B); the activity of G-POX (Figure 6A) increased slightly only in the variant O30.
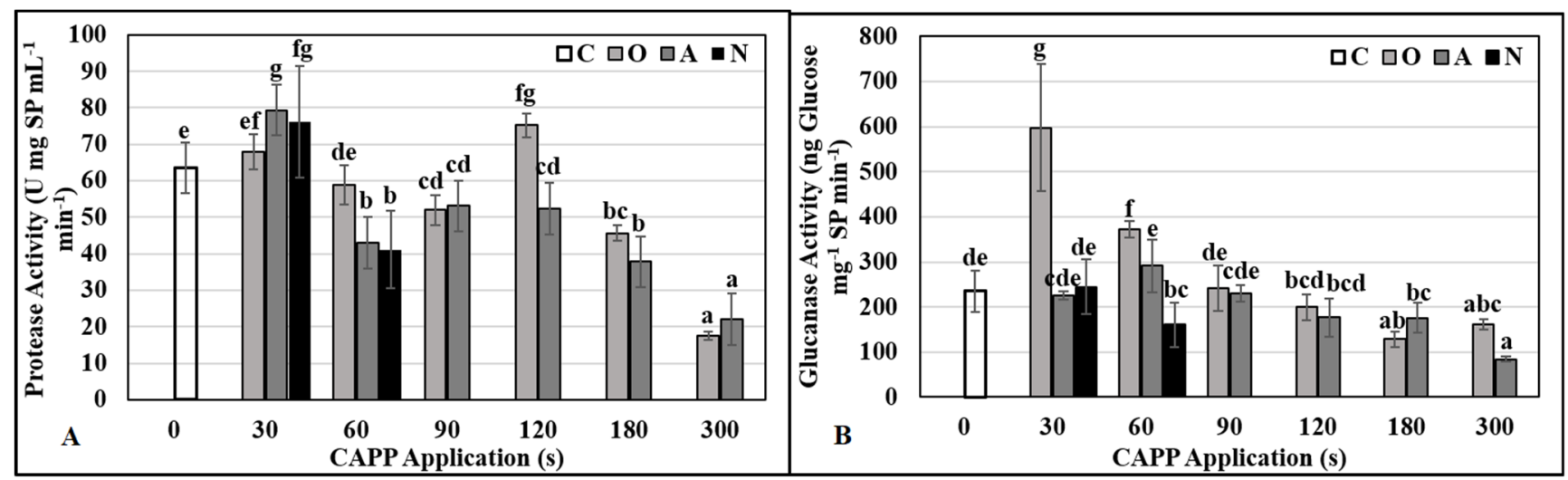

Figure 5. The activity of protease (A) and glucanase (B) in 3-day-old maize seedlings after Cold Atmospheric Pressure Plasma (CAPP) treatment of grains. Variants: C-control/untreated maize grains; O30-O300: maize grains treated with plasma generated in an oxygen atmosphere for 30, 60, 90, 120, 180 or $300 \mathrm{~s}$; A30-A300: maize grains treated with plasma generated in ambient air for 30, 60, 90, 120, 180 or $300 \mathrm{~s}$; N30-N300: maize grains treated with plasma generated in a nitrogen atmosphere for 30, 60, 90, 120, 180 or 300 s. In the case of N90 variant seedlings lagged significantly in development and in N120-300 variants, the maize grains did not germinate, so they are not shown in the graph. Different letters indicate significant difference at $p$-value $<0.05$, bars are means of ten experimental runs (one run represents 50 grains per variant; three $1.5 \mathrm{~g}$ mixed samples were analyzed per one experimental run and each variant for protease and glucanase activities) \pm SD according to LSD ANOVA test.
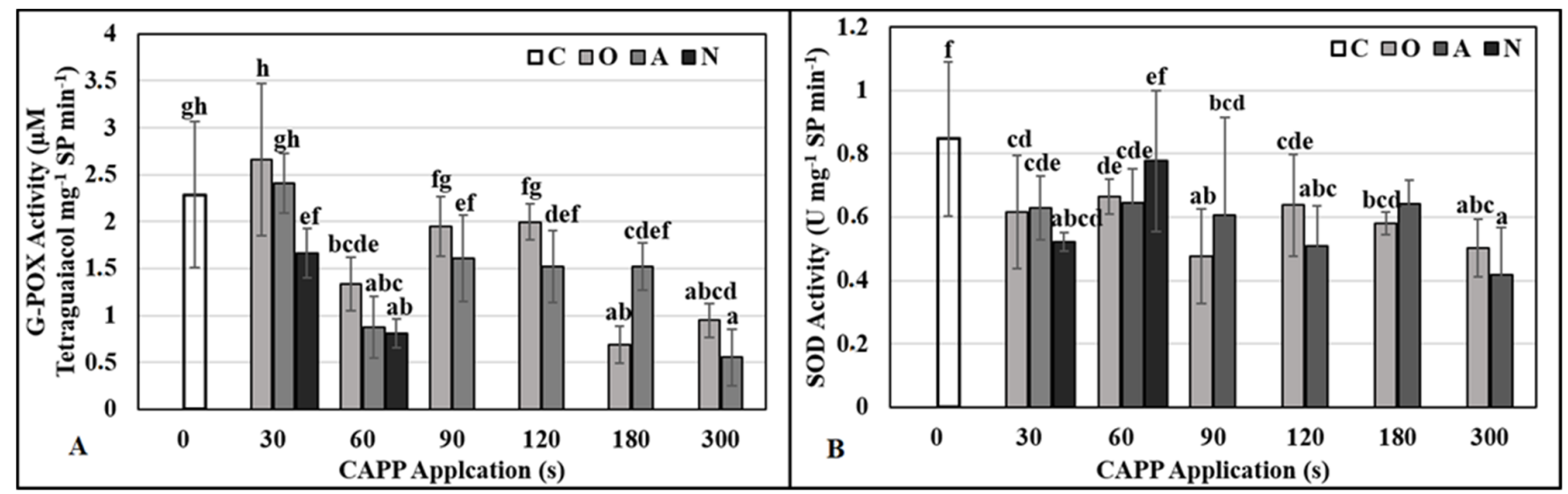

Figure 6. The activity of guaiacol peroxidase (G-POX) (A) and superoxide dismutase (SOD) (B) in 3-day-old maize seedlings after Cold Atmospheric Pressure Plasma (CAPP) treatment of grains. Variants: C-control/untreated maize grains; O30-O300: maize grains treated with plasma generated in an oxygen atmosphere for 30, 60, 90, 120, 180 or 300 s; A30-A300: maize grains treated with plasma generated in ambient air for 30, 60, 90, 120, 180 or 300 s; N30-N300: maize grains treated with plasma generated in a nitrogen atmosphere for 30, 60, 90, 120, 180 or $300 \mathrm{~s}$. In the case of N90 variant seedlings lagged significantly in development and in N120-300 variants, the maize grains did not germinate, so they are not shown in the graph. Different letters indicate significant difference at $p$-value $<0.05$, bars are means of ten experimental runs (one run represents 50 grains per variant; three $1.5 \mathrm{~g}$ mixed samples were analyzed per one experimental run and each variant for guaiacol peroxidase and superoxide dismutase activities) \pm SD according to LSD ANOVA test.

Published works show that high application doses of cold plasma (180 or more seconds) negatively affect the activity of antioxidant enzymes. In pea seeds, the application of CAPP generated in the nitrogen atmosphere leads to a significant accumulation of superoxide radicals which indicates great oxidative stress [19]. This, in combination with 
the low activity of the enzyme SOD, probably causes the production of more toxic ROS and thus severe damage to biological membranes, killing of the embryo, and the inability of these seeds to germinate, as was the case in our experiments. This assumption is also supported by results obtained after applying plasma to soybean seeds [20]. This excessive oxidative stress, which increases in proportion to the plasma exposure time, can be explained by the production of ozone $\left(\mathrm{O}_{3}\right)$ during the generation of plasma in an oxygen atmosphere, nitrogen oxides during generation of plasma in ambient air, and UV radiation during generation of plasma in a nitrogen atmosphere [5], which are harmful in high doses [70-72]. On the other hand, treatment with low-temperature plasma at shorter application doses (60 s) stimulated the activity of antioxidant enzymes. This mild stress, combined with a positive effect on lytic enzyme activity, had a stimulating effect not only on germination but also on the growth, development and overall vitality of young pea and soybean seedlings $[19,20]$ and maize [26]. From the above, it can be stated that mild stress (increased intracellular ROS concentration and slightly increased activity of antioxidant enzymes) caused by short exposure to low-temperature plasma has a positive effect on the processes of germination, growth, and development of young seedlings of different plant species (pea, soybean). In the case of maize (hybrid Ronaldinio) the activity of antioxidant enzymes did not increase due to CAPP treatment.

\subsection{Comet Assay}

The neutral comet assay was used to assess the DNA damage caused by CAPP treatment. Based on the germination percentage, we decided to work only with four treatment times (30-120 s) since the average germination was already significantly decreased at $120 \mathrm{~s}$. We found that the pre-sowing treatment of maize grains with CAPP generated in ambient air did not cause significant damage for shorter treatment times (30-90 s) and was similar to that of negative control (NC; 0 s). There was only a slight increase $(10 \%)$ in DNA damage in the $120 \mathrm{~s}$ variant (Figure 7A). For plasma generated in oxygen, the DNA damage was similar to NC in all variants (30-120 s) (Figure 7B). For CAPP generated in nitrogen, however, there was a slight decrease for the $30 \mathrm{~s}$ treatment (compared to NC). Still, with increasing treatment time, the amount of DNA damage increased as well, up to $30 \%$ for the $120 \mathrm{~s}$ treatment, which was the highest amount of DNA damage caused by CAPP that we detected in this experiment (Figure 7C). The significant amount of oxidative DNA damage was detected mainly after the treatment with CAPP generated in ambient air, but only slight differences were present for CAPP generated in oxygen and nitrogen (Figure 7).

The DNA damage caused by CAPP treatment is usually not excessively high and increases with increasing treatment time, as is shown in other publications [5,19-21]. Our results agree with these works, as most of the variants caused only slight increases of DNA damage or were similar to NC, and the longest treatment times usually had the highest amount of DNA damage. Based on the germination of CAPP-treated maize grains, it seems that nitrogen-CAPP is the most toxic and, indeed, the amount of DNA damage was the highest, especially for the longest treatment times (90 and $120 \mathrm{~s}$ ). In the study of Švubová et al. [19], the DNA damage was also the highest for nitrogen-generated CAPP in pea seedlings. However, in the study of Pet'ková et al. [21], the highest amount of DNA damage was recorded for CAPP generated in ambient air and oxygen in barley. These differences may be due to the different species used in the studies since the effect of plasma treatment is species-specific. Although three-day-old seedlings from grains treated with CAPP generated in ambient air and oxygen do not have high amounts of DNA breaks, they still contain some amount of oxidative DNA damage (more for air CAPP). Similar results were observed for barley [21]. This suggests that there is some level of oxidative stress in cells even a few days after the CAPP treatment. Overall, our results and other studies suggest that NTP treatment, especially for shorter treatment times, do not cause extensive DNA damage. Even though longer treatment times may cause a higher amount of damage, the cells are usually capable of repairing these lesions, provided that DNA 
repair mechanisms are not compromised by NTP treatment. However, in such cases, the germination and growth of seedlings would be compromised as well.
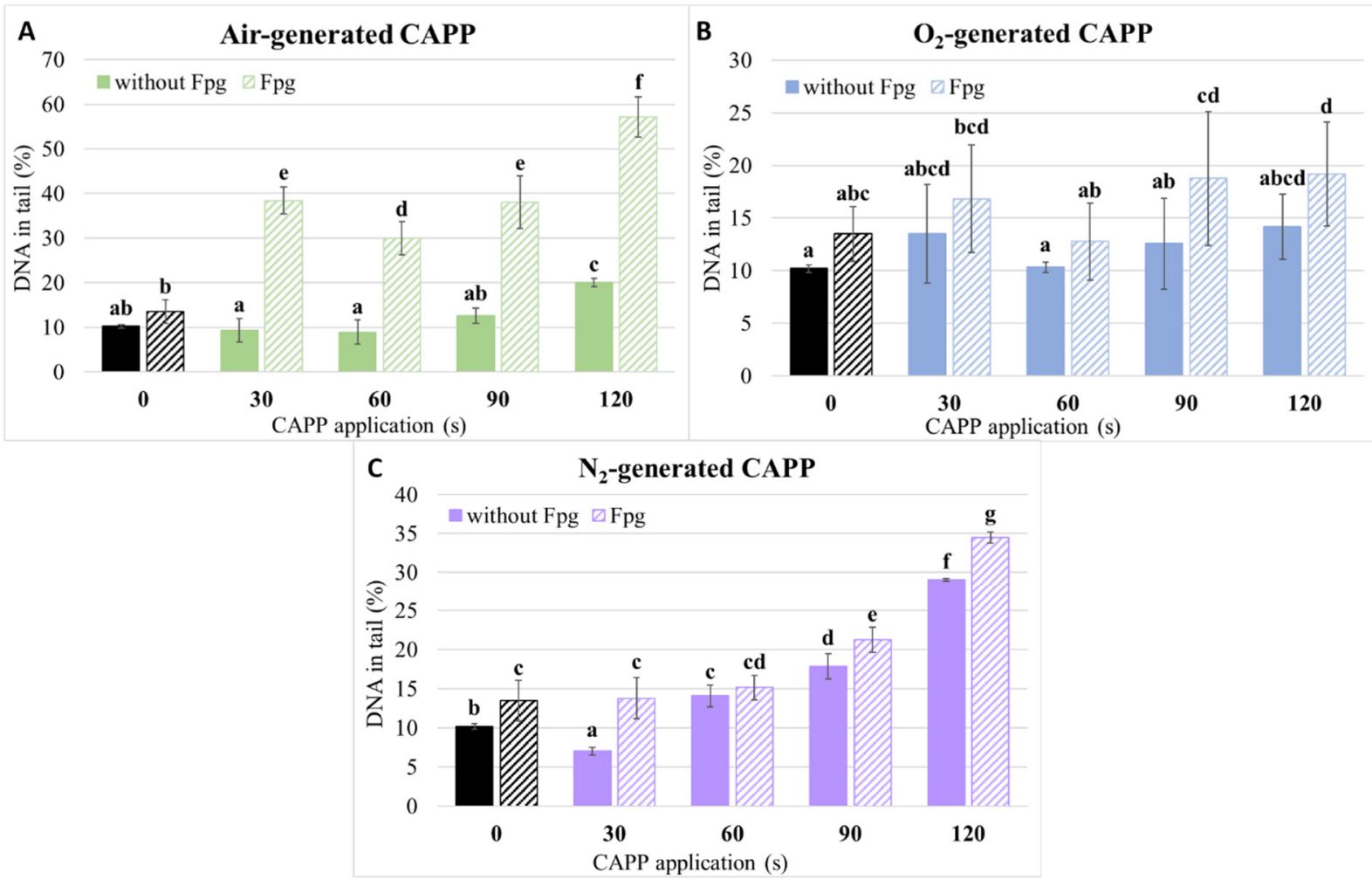

Figure 7. Level of DNA damage in 3-day-old maize seedlings detected by the neutral comet assay and its modification with enzyme formamidopyrimidine glycosylase (Fpg) after the treatment of maize grains with Cold Atmospheric Pressure Plasma (CAPP) generated in ambient air (A), oxygen (B) or nitrogen (C). 0 s-negative control (NC; no treatment); 30, 60, 90 and $120 \mathrm{~s}$ - treatment of grains with CAPP for 30-120 s; at least 100 nuclei were analyzed per slide. The data were analyzed using the statistical method LSD ANOVA and comparisons between the mean values were considered significant at $p 0.05$. Different letters indicate significant difference at $p$-value $<0.05$, bars are the means of three experimental runs \pm SD.

\subsection{Expression of Heat Shock Proteins}

As chaperones, heat shock proteins are essential for the cell not only in development and under normal conditions, but they are also crucial in stressful conditions, as stress often leads to various damages or denaturation of proteins [73]. We monitored the expression of HSP101 and HSP70 genes and heat shock factor gene HSF17 during the $72 \mathrm{~h}$ after sowing by qPCR in samples where dry maize grains were treated with CAPP generated in ambient air.

We noticed that the expression of HSP101 and HSP70 reacted to the CAPP treatment of maize grains in a similar way. Their relative expression at $24 \mathrm{~h}$ increased with increasing CAPP treatment time (30-120 s) compared to the non-treated control (0 s). The expression in plasma-treated samples remained higher even at $48 \mathrm{~h}$ compared to the non-treated control. However, a different trend occurred at $72 \mathrm{~h}$, where the highest expression was in a non-treated sample. At the same time, the CAPP treatment of grains resulted in a lower relative amount of transcripts (about half the amount of that in the control sample) (Figure 8A,B). The role of HSP101 is mainly the dissolving of aggregates, and together with HSP70 also refolding or removal of damaged proteins [74]. Therefore, it is no surprise that we detected a similar trend of expression in reaction to the CAPP treatment for both genes. The increase in the number of transcripts with increasing treatment times also suggests that longer exposure to CAPP causes more damage to proteins, which may also be the reason for the decrease in the activity of enzymes observed in this work. Some authors detected a sharp decrease in the number of HSP101 transcripts in maize shortly after the 
germination $[75,76]$. However, we observed relatively high expression of HSP101 and HSP70 in the control sample at $72 \mathrm{~h}$, and, on the contrary, lower expression in plasmatreated samples. A possible explanation is that it is related to the developmental processes of $72 \mathrm{~h}$ germination of young seedlings. Since the expression of both genes was influenced by CAPP treatment, it is possible that at $72 \mathrm{~h}$, there is higher demand for chaperones in the non-treated control sample than in the CAPP-treated samples, where there was more of them in the past $48 \mathrm{~h}$. Both HSP101 and HSP70 have essential roles during the heat, and other stresses $[77,78]$ and our results suggest that they are also crucial for the reaction to CAPP treatment of seeds. Since their expression increased already at $24 \mathrm{~h}$, the quick action of these two HSPs is needed in response to CAPP treatment as in the reaction to heat stress, where their expression also increased in the first $24 \mathrm{~h}$ according to Lämke et al. [33].

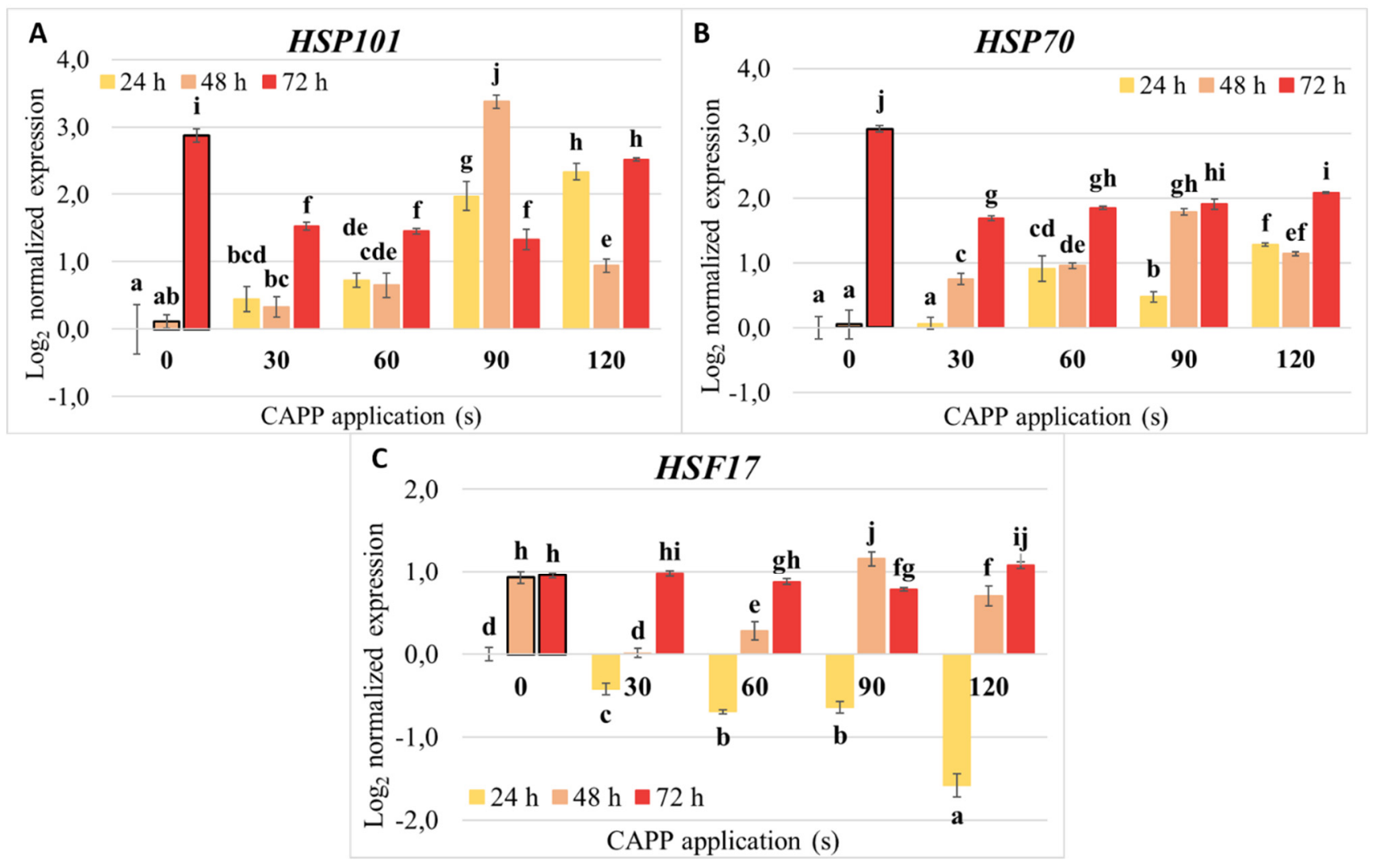

Figure 8. The relative expression of HSP101 (A), HSP70 (B) and HSF17 (C) in maize seedlings, which were treated with Cold Atmospheric Pressure Plasma (CAPP) generated in ambient air as grains for 0, 30, 60, 90 and $120 \mathrm{~s}$, detected at 24, 48 and $72 \mathrm{~h}$ after sowing. Data are normalized to reference genes-tubulin $\beta$ and elongation factor EF $1 \alpha$. The data were analyzed using the statistical method LSD ANOVA and comparisons between the mean values were considered significant at $p$ 0.05. Different letters indicate significant differences between the treatments at $p$-value $<0.05$ level.

Heat shock factors are regulators of HSPs expression. Therefore, we included the HSF17 gene in the analysis of HSPs expression. A homologue of HSF17 in Arabidopsis, HSFA2, is an integral part of the maintenance of acquired thermotolerance in Arabidopsis thaliana [33,34], but it also increases the tolerance of $A$. thaliana to anoxia [32]. We observed that the relative amount of transcripts decreased with increasing CAPP treatment compared to non-treated control at $24 \mathrm{~h}$ after sowing. At $48 \mathrm{~h}$, the amount of transcripts in CAPPtreated samples increased, but in shorter treatment times (30 and $60 \mathrm{~s}$ ), it was still lower than in non-treated control. However, at $72 \mathrm{~h}$, the amount of transcripts was already similar in all variants (Figure $8 \mathrm{C}$ ). The decrease at $24 \mathrm{~h}$ suggests that in the reaction to the CAPP treatment the cells use other heat shock factors than HSF17 to regulate the HSPs expression. Iranbakhsh et al. [79] observed an increase in the expression of HSFA4A in wheat after the 
NTP treatment, which suggests that HSFA4A may have a role in the regulation of HSPs expression in response to the plasma treatment of plants.

\section{Materials and Methods}

\subsection{Plant Material}

Dried maize (Zea mays L. cv. Ronaldinio) grains used in these experiments were obtained from the Central Control and Testing Institute in Agriculture in Bratislava and KWS Semená s.r.o., Bratislava, Slovakia in 2017. Grains were stored in a fridge at $8 \pm 2{ }^{\circ} \mathrm{C}$ in the dark.

\subsection{Plasma Source and Treatment of Maize Grains}

For the plasma treatment of the maize grains, the Diffuse Coplanar Surface Barrier Discharge (DCSBD) [80] was used as a source of cold atmospheric pressure plasma (CAPP). In our experiments, the plasma was generated in ambient air $(\mathrm{A})$, oxygen $(\mathrm{O})$ and nitrogen $(\mathrm{N})$ at atmospheric pressure at the input power of $400 \mathrm{~W}$. The grains were treated for $0 \mathrm{~s}$ (control), 30, 60, 90, 120, 180 and $300 \mathrm{~s}$. The plasma treatment was performed in gas flow regime in a closed chamber with the experimental apparatus described in [5]. The gas flow rate was $3 \mathrm{~L} / \mathrm{min}$. The seeds were placed directly on a ceramic plate of DCSBD system, which was attached on the orbital shaker. The seeds were treated by plasma in dynamic regime at the frequency of $330 \mathrm{rpm}$ to ensure the uniform treatment of grains. Since the area of the active plasma zone is $(8 \times 20) \mathrm{cm}^{2}$, the number of treated seeds at once can be-according to the needs of the experiment and depending on seed size-about 200 pcs (for maize seeds). The DCSBD system was supplied by sinusoidal voltage with peak-to-peak amplitude of $20 \mathrm{kV}$ and frequency $15 \mathrm{kHz}$.

\subsection{ATR-FTIR}

Attenuated Total Reflectance-Fourier Transform Infrared spectroscopy (ATR-FTIR) was used to determine the changes in specific chemical bonds due to the plasma treatment in different working gases on maize grains. Measurements were carried out using spectrometer Bruker Vector 22 with Pike MIRacle accessories (Pike Technologies, Madison, WI USA). The spectra were acquired in the range $4000-500 \mathrm{~cm}^{-1}$ during 20 scans for background/sample and resolution of $4 \mathrm{~cm}^{-1}$.

\subsection{Wettability Properties}

The wettability of the grain surface was evaluated by measurement of water contact angle (WCA) by Drop Shape Analyzer DSA30 (KRÚSS, Hamburg, Germany) with software DSA3. The contact angles of distilled water droplets with a volume of $2 \mu \mathrm{L}$ were measured, and the average value was obtained from at least 10 measurements.

\subsection{Imbibition, Germination and Growth Conditions}

For one experimental run, dry maize grains (50 grains for each variant) were weighed on analytical scales and soaked in sterile distilled water for $4 \mathrm{~h}$ at room temperature. Imbibed grains were blotted dry, weighed again, and wrapped in wet sterile filter paper. Rolls were cultivated in dark conditions in an incubator at $24 \pm 2{ }^{\circ} \mathrm{C}$ for 5 days. During cultivation, the number of germinated grains was counted, and material (seedlings without endosperm) for biochemical analyses was collected after 3 days. After 5 days, the length and weight of shoots and roots of young seedlings were measured. Obtained data were used to calculate germination (\%), germination potential $(\%)$, germination index $(\%)$, grain vitality index (\%), seedling vitality index (\%), and seedling length index according to Abdul-Baki and Anderson [56].

\subsection{Total Soluble Proteins Content}

Samples ( 1.5 g) were ground in liquid nitrogen with mortar and pestle and suspended in $50 \mathrm{mM}$ Na-phosphate protein extraction buffer with $1 \mathrm{mM}$ EDTA, pH 7.8. After 15 min 
centrifugation $(12,000 \times g)$, the supernatant was used to determine protein concentration according to Bradford [60]. Total soluble proteins (SP) concentration was calculated as the amount of total proteins per gram of fresh matter from the calibration curve. We used Bovine Serum Albumin (BSA) as a protein standard.

\subsection{Assay on Lytic Enzymes Assessment}

The activity of $\beta-1,3-$ Glucanase was assayed by measuring the rate of release of reducing sugar from laminarin (Sigma-Aldrich Co., Bratislava, Slovakia) as a substrate according to the methodology by Somogy [81] and Nelson [82]. Absorbance was measured by a spectrophotometer Jenway $6705 \mathrm{UV} /$ Vis (Bibby Scientific Ltd., Essex, UK) at $660 \mathrm{~nm}$. Total enzyme activity was calculated from the calibration curve where the glucose was used as a standard. Glucanase activity was expressed in nMol of glucose $\mathrm{min}^{-1} \mathrm{mg}^{-1}$ of soluble proteins. Changes in the activity of protease in 3-day-old soybean seedlings were determined according to the methodology by Matušíková et al. [83]. The absorbance of the supernatant at $280 \mathrm{~nm}$ was measured by a spectrophotometer Jenway $6705 \mathrm{UV} / \mathrm{Vis}$ (Bibby Scientific Ltd., Essex, UK). One unit of proteolytic activity was defined as an increase of 0.001 in the absorbance at $280 \mathrm{~nm}$ per minute.

\subsection{Assay on Antioxidant Enzymes Assessment}

The activity of enzymes that detoxify ${ }^{\circ} \mathrm{O}_{2}{ }^{-}$(superoxide dismutase (SOD), E.C.1.15.1.1) and $\mathrm{H}_{2} \mathrm{O}_{2}$ (guaiacol peroxidase (G-POX), E.C.1.11.1.7) was monitored. The activity of SOD was established according to Beauchamp and Fridowich [84] and the G-POX according to Frič and Fuchs [85]. One unit of SOD activity was the amount of proteins required to inhibit $50 \%$ of the initial reduction of Nitrotetrazolium Blue Chloride (NBT) under the light $\min ^{-1} \mathrm{mg}^{-1}$ of soluble proteins. Guaiacol peroxidase activity was expressed in $\mu \mathrm{M}$ of tetraguaiacol $\mathrm{min}^{-1} \mathrm{mg}^{-1}$ of soluble proteins by molar extinction coefficient of tetraguaiacol 26.6 according to Chance and Maehly [86]. Chemicals were purchased from Sigma-Aldrich Co. (Bratislava, Slovakia).

\subsection{Comet Assay}

A neutral version of the comet assay was performed. The nuclei were isolated from 3-day-old maize seedlings using the slicing method with a sharp razor blade in $150 \mu \mathrm{L}$ of ice-cold PBS (160 mM NaCl, $8 \mathrm{mM} \mathrm{Na}_{2} \mathrm{HPO}_{4}, 4 \mathrm{mM} \mathrm{NaH} \mathrm{PO}_{4}, 50 \mathrm{mM}$ EDTA, pH 7) set on ice. For each sample, two roots were used, approximately one centimeter from the apex but excluding the root apex. The suspension of nuclei $(100 \mu \mathrm{L})$ was mixed with $100 \mu \mathrm{L}$ of $1 \%$ low melting point agarose (LMP), pipetted onto slides precoated with $1 \%$ normal melting point agarose, and covered with a coverslip. The nuclei fixed in LMP agarose on microscopic slides were lysed in cold high salt buffer $(2.5 \mathrm{M} \mathrm{NaCl}, 100 \mathrm{mM}$ EDTA, $10 \mathrm{mM}$ Tris-HCl pH 7.5) for $20 \mathrm{~min}$. Subsequently, electrophoresis was performed in 1x TBE (90 mM Tris- $\mathrm{HCl} \mathrm{pH} 8.4,90 \mathrm{mM}$ Boric acid, $2 \mathrm{mM}$ EDTA) at $1 \mathrm{~V} / \mathrm{cm}$ at room temperature for $6 \mathrm{~min}$. The slides were then dehydrated for $5 \mathrm{~min}$ in $75 \%$ ethanol and $5 \mathrm{~min}$ in $96 \%$ ethanol, left to dry and stored for subsequent evaluation. Nuclei were stained with $15 \mu \mathrm{L}$ of $0.05 \mathrm{mM}$ ethidium bromide for each mini gel on the slide. The stained nuclei were observed using fluorescence microscope OLYMPUS BX 51 with a green excitation filter UMWIG3 under 200× magnification and at least 100 nuclei per slide were evaluated by the visual scoring method [87].

The formamidopyrimidine (Fpg)-modified comet assay was based on a neutral comet assay described before with the Fpg additional steps according to Horváthová et al. [88]. Briefly, after the lysis step, the slides were washed three times for 5 min with an enzyme reaction buffer (40 $\mathrm{mM}$ HEPES, $0.5 \mathrm{mM}$ EDTA, $0.1 \mathrm{M} \mathrm{KCl}, 0.2 \mathrm{mg} / \mathrm{mL}$ BSA, pH 8). Then, $0.2 \mathrm{U}(40 \mu \mathrm{L})$ of the enzyme was added to each mini gel on the slide and the gels were then covered with a coverslip. The same amount of enzyme reaction buffer (instead of Fpg) was added to a parallel series of samples and covered with a coverslip. Both series were placed into a thermostat at $37^{\circ} \mathrm{C}$ for $30 \mathrm{~min}$. After the incubation, coverslips were 
removed, slides were washed $3 \times 5 \mathrm{~min}$ in $1 \times \mathrm{TBE}$ and the protocol continued with the step of electrophoresis as in the standard neutral comet assay.

As a negative control (NC), seedlings not pre-treated with CAPP or any other agent were used.

\subsection{0. $R T-P C R$}

All the experiments from RNA extraction to real-time PCR were performed by available commercial kits according to the manufacturer's instructions. RNA was isolated from maize seedlings that were treated with CAPP generated in ambient air as grains, at 24, 48 and $72 \mathrm{~h}$ after sowing. For each sample, 2-3 seedlings without endosperm were used. Seedlings were immediately frozen in liquid nitrogen and ground with mortar and pestle. Total RNA was isolated using Spectrum Plant Total RNA Kit (Sigma-Aldrich, Bratislava, Slovakia). The RNA samples were treated with DNase I enzyme, purified and concentrated using RNA Clean \& Concentrator ${ }^{\mathrm{TM}}-5$ columns (BioRad, Prague, Czech Republic). The concentration and purity of total RNA were measured with spectrophotometer Nanodrop 1000 (ThermoFisher Scientific, Prague, Czech Republic). The RNA integrity was checked by denaturing agarose gel electrophoresis [89]. Using iScript cDNA Synthesis Kit (BioRad, Prague, Czech Republic), the cDNA was synthesized by reverse transcription of $1 \mu \mathrm{g}$ of total RNA. cDNA samples were used to assess the relative expression of chosen genes using qPCR. Specific transcripts were amplified using Luna ${ }^{\circledR}$ Universal qPCR Master Mix (New England Biolabs, Ipswich, MA, USA) in thermocycler LightCyclerII 480 (Roche, Rotkreuz, Switzerland) with the set of primers listed in Table 2.

Table 2. Sequences of primers for chosen heat shock protein genes.

\begin{tabular}{ccc}
\hline Gene & Primer & Primer Sequence $\mathbf{( 5}^{\prime}$-> $^{\prime}$ ) \\
\hline \multirow{2}{*}{ HSP101 (NM_001111465.2) } & HSP101_F & CGAGGTACATCATGGGTCGG \\
& HSP101_R & GGCTTTACTGGCCTTGTCCT \\
\hline \multirow{2}{*}{ HSP70 (NM_001196236.1) } & HSP70_F & AGCTTGAGGGGATCTGCAAC \\
& HSP70_R & CCTCACCAAACCAAACCTCG \\
\hline \multirow{2}{*}{ HSF17 (MK736813.1) } & HSF17_F & GCCTGATTGGGCCACATGAT \\
& HSF17_R & CAGGGCTATCGTTCTCCTCG \\
\hline
\end{tabular}

As reference genes, $\beta$-tubulin and elongation factor EF1 $\alpha$ were used with the set of primers listed in Table 3.

Table 3. Sequences of primers for chosen reference genes.

\begin{tabular}{ccc}
\hline Gene & Primer & Primer Sequence $\left(\mathbf{5}^{\prime} \boldsymbol{- > \mathbf { 3 } ^ { \prime } )}\right.$ \\
\hline \multirow{2}{*}{ EF1A (NM_001112117.2) } & EF1 $\alpha \_F$ & TGGGCCTACTGGTCTTACTACTGA \\
& EF1 $\alpha \_R$ & ACATACCCACGCTTCAGATCCT \\
\hline \multirow{2}{*}{ TUB B (NM_001112218.1) } & TUB $\beta \_F$ & CTACCTCACGGCATCTGCTATGT \\
& TUB $\beta \_R$ & GTCACACACACTCGACTTCACG \\
\hline
\end{tabular}

Primers were designed using the online tool Primer-BLAST (http:/ / www.ncbi.nlm. nih.gov/tools/primer-blast/; accessed on 4 November 2020) from sequences in the NCBI database.

Fluorescent quantification of products in individual samples took place during polymerization using SYBR/FAM filter. The specificity of PCR products was confirmed by agarose gel electrophoresis and melt curve analysis, which was included at the end of each run of the qPCR reaction. The sequencing of PCR products was performed by the Sanger method at the Department of Molecular Biology (Faculty of Natural Sciences, Comenius University). Sequences were analyzed using the program Sequencing Analysis 
software (version 5.4, Applied Biosystems, Waltham, MA, USA) and verified by the Blast bioinformatic tool (http:/ / blast.ncbi.nlm.nih.gov/Blast.cgi; accessed on 12 January 2021).

\subsection{Statistical Analysis}

The data were analyzed using Microsoft Excel (Microsoft Office 2013, Redmond, WA, USA) and Statgraphic Centurion 19 (Statgraphics Technologies, Inc., The Plains, Virginia). Treatment effects were investigated by means of ANOVA single-step multiple comparisons using LSD test, and comparisons between the mean values were considered significant at $p<0.05$. All experimental data in this work are from at least three independent experiments.

Relative change in gene expression was estimated according to Taylor et al. [90] including gene amplification efficiencies. Statistical analysis (ANOVA and LSD test) of gene expression data was based on the $\log _{2}$ transformed normalized expression per sample.

\section{Conclusions}

Cold atmospheric pressure plasma has a potential to be used in agriculture for seed treatment for more environmentally friendly production of various crops. Until then, it is necessary to study its effects on various plants to gain a holistic view and to be able to design optimal treatment conditions for the desired outcomes.

The presented work focused on the effects of CAPP treatment of maize grains. We found that after the treatment, the wettability of grain surface increased and also the amount of water taken up by the grains during imbibition was higher. The surface diagnostics using ATR-FTIR did not show damage of the surface chemical bonds of the grains after plasma treatment. The CAPP generated by DCSBD plasma source is characterized by high volume power density, so short plasma treatment times are enough to achieve a substantial improvement of seed germination and the vitality of grains and young seedlings. However, higher doses of CAPP (90 or more seconds) had more of a negative impact on growth and production indexes. Specifically, higher doses of CAPP generated in nitrogen completely inhibited germination. The increased amount of soluble proteins was observed after the plasma treatment which can be caused by mobilization of storage proteins by proteases. The activities of antioxidant enzymes in variants treated with air and oxygen plasma were lower or comparable to the negative control, suggesting that the oxidative stress in three-day-old maize seedlings, which were treated with CAPP as grains, was not that high Prolonged exposure to nitrogen plasma led to a reduction (N90) or complete inhibition (N120-300) of germination, which could be due to excessive oxidative stress and the inability of the antioxidant system to buffer it. A slight increase in DNA damage caused by CAPP treatment was detected, but mostly for longer treatment times. There was also a noticeable level of oxidative DNA damage, especially for ambient air-generated CAPP, however, these were primary DNA damage and cells are capable repairing them. We also found that HSF17 is probably not needed for the regulation of HSPs expression in response to CAPP treatment. On the other hand, the expression of HSP101 and HSP70 genes was induced by CAPP treatment, mostly at the first $48 \mathrm{~h}$ after sowing, which suggested that the quick action of molecular chaperones is needed shortly after CAPP treatment.

Author Contributions: Conceptualization, L'.H., R.Š., L'S., V.M., A.Z. and E.G.; Formal analysis, L'.H., R.Š., L'S., B.B. and V.M.; Funding acquisition, A.Z. and E.G.; Investigation, L'.H., R.Š., L'S., B.B., V.C.K., J.R., F.U. and V.M.; Project administration, A.Z. and E.G.; Resources, B.B., A.Z. and E.G.; Supervision, A.Z. and E.G.; Validation, L'.H., R.Š., L'.S., B.B. and V.M.; Visualization, L'.H., R.Š., L'.S., B.B. and V.M.; Writing—original draft, L'.H., R.Š., L'S., V.M., A.Z. and E.G.; Writing-review and editing, L'.H., R.Š., L'S., B.B., V.M., A.Z. and E.G. All authors have read and agreed to the published version of the manuscript.

Funding: This research was funded by the Slovak Research and Development Agency under the Contract No. APVV-16-0216; by the Slovak Grant Agency VEGA, by the VEGA grant No. 1/0460/21. This work was also the result of the project implementation: Comenius University in Bratislava Science Park supported by the Research and Development Operational Programme funded by the ERDF (Grant No. ITMS 26240220086). 
Institutional Review Board Statement: Not applicable.

Informed Consent Statement: Not applicable.

Acknowledgments: We would like to thank Juliana Tomeková for help with the plasma treatment of maize grains and Dušan Zorkócy for English language revision.

Conflicts of Interest: The authors declare no conflict of interest.

\section{References}

1. OECD/FAO. OECD-FAO Agricultural Outlook 2020-2029; FAO, Ed.; OECD Publishing: Paris, France, 2020. [CrossRef]

2. Laroussi, M. Low temperature plasma-based sterilization: Overview and state-of-the-art. Plasma Process. Polym. 2005, 2, 391-400. [CrossRef]

3. Pankaj, S.K.; Wan, Z.; Keener, K.M. Effects of cold plasma on food quality: A review. Foods 2018, 7, 4. [CrossRef] [PubMed]

4. Šimončicová, J.; Kryštofová, S.; Medvecká, V.; Ďurišová, K.; Kaliňáková, B. Technical applications of plasma treatments: Current state and perspectives. Appl. Microbiol. Biotechnol. 2019, 103, 5117-5129. [CrossRef] [PubMed]

5. Tomeková, J.; Kyzek, S.; Medvecká, V.; Gálová, E.; Zahoranová, A. Influence of cold atmospheric pressure plasma on pea seeds: DNA damage of seedlings and optical diagnostics of plasma. Plasma Chem. Plasma Process. 2020, 40, 1571-1584. [CrossRef]

6. Stolárik, T.; Henselová, M.; Martinka, M.; Novák, O.; Zahoranová, A.; Černák, M. Effect of low-temperature plasma on the structure of seeds, growth and metabolism of endogenous phytohormones in pea (Pisum sativum L.). Plasma Chem. Plasma Process. 2015, 35, 659-676. [CrossRef]

7. Meng, Y.; Qu, G.; Wang, T.; Sun, Q.; Liang, D.; Hu, S. Enhancement of germination and seedling growth of wheat seed using dielectric barrier discharge plasma with various gas sources. Plasma Chem. Plasma Process. 2017, 37, 1105-1119. [CrossRef]

8. Pérez-Pizá, M.C.; Prevosto, L.; Grijalba, P.E.; Zilli, C.G.; Cejas, E.; Mancinelli, B.; Balestrasse, K.B. Improvement of growth and yield of soybean plants through the application of non-thermal plasmas to seeds with different health status. Heliyon 2019, 5, e01495. [CrossRef]

9. Los, A.; Ziuzina, D.; Boehm, D.; Cullen, P.J.; Bourke, P. Investigation of mechanisms involved in germination enhancement of wheat (Triticum aestivum) by cold plasma: Effects on seed surface chemistry and characteristics. Plasma Process. Polym. 2019, 16, 1-12. [CrossRef]

10. Lee, Y.; Lee, Y.Y.; Kim, Y.S.; Balaraju, K.; Mok, Y.S.; Yoo, S.J.; Jeon, Y. Enhancement of seed germination and microbial disinfection on ginseng by cold plasma treatment. J. Ginseng Res. 2020, in press. [CrossRef]

11. Taheri, S.; Brodie, G.I.; Gupta, D.; Jacob, M.V. Afterglow of atmospheric non-thermal plasma for disinfection of lentil seeds from botrytis grey mould. Innov. Food Sci. Emerg. Technol. 2020, 66, 102488. [CrossRef]

12. Puligundla, P.; Kim, J.W.; Mok, C. Effects of nonthermal plasma treatment on decontamination and sprouting of radish (Raphanus sativus L.) seeds. Food Bioprocess. Technol. 2017, 10, 1093-1102. [CrossRef]

13. Pechanova, O.; Pechan, T. Maize-pathogen interactions: An ongoing combat from a proteomics perspective. Int. J. Mol. Sci. 2015, 16, 28429-28448. [CrossRef] [PubMed]

14. Bormashenko, E.; Shapira, Y.; Grynyov, R.; Whyman, G.; Bormashenko, Y.; Drori, E. Interaction of cold radiofrequency plasma with seeds of beans (Phaseolus vulgaris). J. Exp. Bot. 2015, 66, 4013-4021. [CrossRef]

15. Volkov, A.G.; Hairston, J.S.; Patel, D.; Gott, R.P.; Xu, K.G. Cold Plasma poration and corrugation of pumpkin seed coats. Bioelectrochemistry 2019, 128, 175-185. [CrossRef]

16. Khamsen, N.; Onwimol, D.; Teerakawanich, N.; Dechanupaprittha, S.; Kanokbannakorn, W.; Hongesombut, K.; Srisonphan, S. Rice (Oryza sativa L.) seed sterilization and germination enhancement via atmospheric hybrid nonthermal discharge plasma. ACS Appl. Mater. Interfaces 2016, 8, 19268-19275. [CrossRef]

17. Bormashenko, E.; Grynyov, R.; Bormashenko, Y.; Drori, E. Cold radiofrequency plasma treatment modifies wettability and germination speed of plant seeds. Sci. Rep. 2012, 2, 741. [CrossRef]

18. Vajpayee, M.; Singh, M.; Ledwani, L. Non-thermal plasma treatment of cellulosic biopolymer to enhance its surface property for various applications: A Review. Mater. Today Proc. 2021, 43, 3250-3255. [CrossRef]

19. Švubová, R.; Kyzek, S.; Medvecká, V.; Slováková, L’.; Gálová, E.; Zahoranová, A. Novel insight at the effect of cold atmospheric pressure plasma on the activity of enzymes essential for the germination of pea (Pisum sativum L. cv. Prophet) Seeds. Plasma Chem. Plasma Process. 2020, 40, 1221-1240. [CrossRef]

20. Švubová, R.; Slováková, L.; Holubová, L.; Rovňanová, D.; Gálová, E.; Tomeková, J. Evaluation of the impact of cold atmospheric pressure plasma on soybean seed germination. Plants 2021, 10, 177. [CrossRef]

21. Pet'ková, M.; Švubová, R.; Kyzek, S.; Medvecká, V.; Slováková, L.; Ševčovičová, A.; Gálová, E. The effects of cold atmospheric pressure plasma on germination parameters, enzyme activities and induction of DNA damage in barley. Int. J. Mol. Sci. 2021, 22, 2833. [CrossRef]

22. Cui, D.; Yin, Y.; Wang, J.; Wang, Z.; Ding, H.; Ma, R.; Jiao, Z. Research on the physio-biochemical mechanism of non-thermal plasma-regulated seed germination and early seedling development in Arabidopsis. Front. Plant. Sci. 2019, 10, 1322. [CrossRef]

23. Billah, M.; Sajib, S.A.; Roy, N.C.; Rashid, M.M.; Reza, M.A.; Hasan, M.M.; Talukder, M.R. Effects of DBD air plasma treatment on the enhancement of black gram (Vigna mungo 1.) seed germination and growth. Arch. Biochem. Biophys. 2020, 681, 108253. [CrossRef] 
24. Guo, Q.; Wang, Y.; Zhang, H.; Qu, G.; Wang, T.; Sun, Q.; Liang, D. Alleviation of adverse effects of drought stress on wheat seed germination using atmospheric dielectric barrier discharge plasma treatment. Sci. Rep. 2017, 7, 1-14. [CrossRef] [PubMed]

25. Zhang, J.J.; Jo, J.O.; Huynh, D.L.; Mongre, R.K.; Ghosh, M.; Singh, A.K.; Lee, S.B.; Mok, Y.S.; Hyuk, P.; Jeong, D.K. Growth-inducing effects of argon plasma on soybean sprouts via the regulation of demethylation levels of energy metabolism-related genes. Sci. Rep. 2017, 7, 1-12. [CrossRef]

26. Henselová, M.; Slováková, L'.; Martinka, M.; Zahoranová, A. Growth, anatomy and enzyme activity changes in maize roots induced by treatment of seeds with low-temperature plasma. Biologia 2012, 67, 490-497. [CrossRef]

27. Tong, J.; He, R.; Zhang, X.; Zhan, R.; Chen, W.; Yang, S. Effects of atmospheric pressure air plasma pretreatment on the seed germination and early growth of Andrographis paniculata. Plasma Sci. Technol. 2014, 16, 260-266. [CrossRef]

28. Zahoranová, A.; Henselová, M.; Hudecová, D.; Kaliňáková, B.; Kováčik, D.; Medvecká, V.; Černák, M. Effect of cold atmospheric pressure plasma on the wheat seedlings vigor and on the inactivation of microorganisms on the seeds surface. Plasma Chem. Plasma Process. 2016, 36, 397-414. [CrossRef]

29. Puač, N.; Petrović, Z.L.; Živković, S.; Giba, Z.; Grubbišić, D.; Dordević, A.R. Low-temperature plasma treatment of dry empresstree seeds. In Plasma Processes and Polymers; d'Agostino, R., Favia, P., Oehr, C., Wertheimer, M.R., Eds.; Wiley-VCH: Weinheim, Germany, 2005; pp. 193-203. [CrossRef]

30. Štěpánová, V.; Slavíček, P.; Kelar, J.; Prášil, J.; Smékal, M.; Stupavská, M.; Jurmanová, J.; Černák, M. Atmospheric pressure plasma treatment of agricultural seeds of cucumber (Cucumis sativus L.) and pepper (Capsicum annuum L.) with effect on reduction of diseases and germination improvement. Plasma Process. Polym. 2018, 15, 1700076. [CrossRef]

31. Banzet, N.; Richaud, C.; Deveaux, Y.; Kazmaier, M.; Gagnon, J.; Triantaphylidés, C. Accumulation of small heat shock proteins, including mitochondrial HSP22, induced by oxidative stress and adaptive response in tomato cells. Plant. J. 1998, 13, 519-527. [CrossRef]

32. Banti, V.; Mafessoni, F.; Loreti, E.; Alpi, A.; Perata, P. The heat-inducible transcription factor HsfA2 enhances anoxia tolerance in Arabidopsis. Plant. Physiol. 2010, 152, 1471-1483. [CrossRef]

33. Lämke, J.; Brzezinka, K.; Altmann, S.; Bäurle, I. A Hit-and-run heat shock factor governs sustained histone methylation and transcriptional stress memory. EMBO J. 2016, 35, 162-175. [CrossRef] [PubMed]

34. Charng, Y.Y.; Liu, H.C.; Liu, N.Y.; Chi, W.T.; Wang, C.N.; Chang, S.H.; Wang, T.T. A heat-inducible transcription factor, HsfA2, is required for extension of acquired thermotolerance in Arabidopsis. Plant. Physiol. 2007, 143, 251-262. [CrossRef] [PubMed]

35. Pérez-Salamó, I.; Papdi, C.; Rigó, G.; Zsigmond, L.; Vilela, B.; Lumbreras, V.; Nagy, I.; Horváth, B.; Domoki, M.; Darula, Z.; et al. The heat shock factor A4A confers salt tolerance and is regulated by oxidative stress and the mitogen-activated protein. Plant. Physiol. 2014, 165, 319-334. [CrossRef] [PubMed]

36. Basile, A.; Sorbo, S.; Cardi, M.; Lentini, M.; Castiglia, D.; Cianciullo, P.; Conte, B.; Loppi, S.; Esposito, S. Effects of heavy metals on ultrastructure and Hsp70 induction in Lemna minor L. exposed to water along the Sarno river, Italy. Ecotoxicol. Environ. Saf. 2015, 114, 93-101. [CrossRef] [PubMed]

37. Vasques, C.T.; Domenech, S.C.; Severgnini, V.L.S.; Belmontte, L.A.O.; Barreto, P.L.M.; Soldi, V. Effect of thermal treatment on the stability and structure of maize starch cast films. Starch/Stärke 2007, 59, 161-170. [CrossRef]

38. Kuhnen, S.; Ogliari, J.B.; Dias, P.F.; Boffo, E.F.; Correia, I.; Ferreira, G.; Delgadillo, I.; Maraschin, M. ATR-FTIR spectroscopy and chemometric analysis applied to discrimination of landrace maize flours produced in southern Brazil. Int. J. Food Sci. Technol. 2010, 45, 1673-1681. [CrossRef]

39. Miao, M.; Li, R.; Huang, C.; Jiang, B.; Zhang, T. Impact of B-amylase degradation on properties of sugary maize soluble starch particles. Food Chem. 2015, 177, 1-7. [CrossRef]

40. Warren, F.J.; Gidley, M.J.; Flanagan, B.M. Infrared spectroscopy as a tool to characterise starch ordered structure-A joint FTIR-ATR, NMR, XRD and DSC study. Carbohydr. Polym. 2016, 139, 35-42. [CrossRef]

41. Jayaram, S.; Kapoor, S.; Dharmesh, S.M. Pectic polysaccharide from corn (Zea mays L.) effectively inhibited multi-step mediated cancer cell growth and metastasis. Chem. Biol. Interact. 2015, 235, 63-75. [CrossRef]

42. Bewley, J.D.; Black, M. Chapter 4. Imbibition, germination, and growth. In Physiology and Biochemistry of Seeds in Relation to Germination; Springer: Berlin/Heidelberg, Germany, 1978; pp. 106-131. [CrossRef]

43. Miano, A.C.; Augusto, P.E.D. The hydration of grains: A critical review from description of phenomena to process improvements. Compr. Rev. Food Sci. Food Saf. 2018, 17, 352-370. [CrossRef]

44. Bewley, J.D.; Bradford, K.J.; Hilhorst, H.W.M.; Nonogaki, H. Seeds—Physiology of Development, Germination and Dormancy, 3rd ed.; Springer: New York, NY, USA, 2013. [CrossRef]

45. Hou, J.Q.; Kendall, E.J.; Simpson, G.M. Water uptake and distribution in non-dormant and dormant wild oat (Avena fatua L.) caryopses. J. Exp. Bot. 1997, 48, 683-692. [CrossRef]

46. Yin, M.; Huang, M.; Ma, B.; Ma, T. Stimulating effects of seed treatment by magnetized plasma on tomato growth and yield. Plasma Sci. Technol. 2005, 7, 3143-3147.

47. Dubinov, A.E.; Lazarenko, E.M.; Selemir, V.D. Effect of glow discharge air plasma on grain crops seed. IEEE Trans. Plasma Sci. 2000, 28, 180-183. [CrossRef]

48. Mitra, A.; Li, Y.; Klämpfl, T.G.; Shimizu, T.; Jeon, J.; Morfill, G.E.; Zimmermann, J.L. Inactivation of surface-borne microorganisms and increased germination of seed specimen by cold atmospheric plasma. Food Bioprocess. Technol. 2014, 7, 645-653. [CrossRef] 
49. Wang, X.; Zhou, R.; De Groot, G.; Bazaka, K.; Murphy, A.B.; Ostrikov, K.K. Spectral characteristics of cotton seeds treated by a dielectric barrier discharge plasma. Sci. Rep. 2017, 7, 5601:1-5601:9. [CrossRef]

50. Zahoranová, A.; Hoppanová, L.; Šimončicová, J.; Tučeková, Z.; Medvecká, V.; Hudecová, D.; Kaliňáková, B.; Kováčik, D.; Černák, M. Effect of cold atmospheric pressure plasma on maize seeds: Enhancement of seedlings growth and surface microorganisms inactivation. Plasma Chem. Plasma Process. 2018, 38, 969-988. [CrossRef]

51. Dobrin, D.; Magureanu, M.; Mandache, N.B.; Ionita, M.D. The effect of non-thermal plasma treatment on wheat germination and early growth. Innov. Food Sci. Emerg. Technol. 2015, 29, 255-260. [CrossRef]

52. Vashisth, A.; Nagarajan, S. Characterization of water distribution and activities of enzymes during germination in magneticallyexposed maize (Zea mays L) Seeds. Indian J. Biochem. Biophys. 2010, 47, 311-318.

53. Computer and computing technologies in agriculture VIII. In Proceedings of the 8th IFIP WG 5.14 International Conference, CCTA 2014, Beijing, China, 16-19 September 2014; Volume 258, p. 756. [CrossRef]

54. Feng, J.; Pang, A.; Wang, D.; Wang, G.; Liu, L.; Shao, C.; He, C. Effect of different time and power of low-temperature helium plasma on germination characteristics of maize (Zea mays L.). In Proceedings of the 2016 American society of agricultural and biological engineers annual international meeting, Orlando, FL, USA, 17-20 July 2016; pp. 2-7. [CrossRef]

55. Karmakar, S.; Billah, M.; Hasan, M.; Sohan, S.R.; Hossain, M.F.; Faisal Hoque, K.M.; Kabir, A.H.; Rashid, M.M.; Talukder, M.R.; Reza, M.A. Impact of LFGD (Ar+O2) plasma on seed surface, germination, plant growth, productivity and nutritional composition of maize (Zea mays L.). Heliyon 2021, 7, e06458. [CrossRef]

56. Abdul-Baki, A.A.; Anderson, J.D. Vigor determination in soybean seed by multiple criteria. Crop. Sci. 1973, 13, 630-633. [CrossRef]

57. Zafar, S.; Ashraf, M.Y.; Ashraf, M. Protease activity and associated changes during germination and early seedling stages of cotton grown under saline conditions. Int. J. Bot. 2005, 1, 103-107. [CrossRef]

58. Tsuji, A.; Tsukamoto, K.; Iwamoto, K.; Ito, Y.; Yuasa, K. Enzymatic characterization of germination-specific cysteine protease-1 expressed transiently in cotyledons during the early phase of germination. J. Biochem. 2013, 153, 73-83. [CrossRef] [PubMed]

59. Müntz, K.; Belozersky, M.A.; Dunaevsky, Y.E.; Schlereth, A.; Tiedemann, J. Stored proteinases and the initiation of storage protein mobilization in seeds during germination and seedling growth. J. Exp. Bot. 2001, 52, 1741-1752. [CrossRef] [PubMed]

60. Bradford, M.M. A Rapid and sensitive method for the quantitation of microgram quantities of protein utilizing the principle of protein-dye binding. Anal. Biochem. 1976, 72, 248-254. [CrossRef]

61. Kim, H.T.; Choi, U.; Ryu, H.S.; Lee, S.J.; Kwon, O. Mobilization of storage proteins in soybean seed (Glycine max L.) during germination and seedling growth. BBA Proteins Proteom. 2011, 1814, 1178-1187. [CrossRef]

62. Sadhu, S.; Thirumdas, R.; Deshmukh, R.R.; Annapure, U.S. Influence of cold plasma on the enzymatic activity in germinating mung beans (Vigna radiate). LWT Food Sci. Technol. 2017, 78, 97-104. [CrossRef]

63. Ling, L.; Jiangang, L.; Minchong, S.; Chunlei, Z.; Yuanhua, D. Cold plasma treatment enhances oilseed rape seed germination under drought stress. Sci. Rep. 2015, 5, 1-10. [CrossRef]

64. Su, L.; Lan, Q.; Pritchard, H.W.; Xue, H.; Wang, X. Reactive oxygen species induced by cold stratification promote germination of Hedysarum scoparium seeds. Plant. Physiol. Biochem. 2016, 109, 406-415. [CrossRef]

65. Balasubramanian, B.; Pogozelski, W.K.; Tullius, T.D. DNA strand breaking by the hydroxyl radical is governed by the accessible surface areas of the hydrogen atoms of the DNA backbone. Proc. Natl. Acad. Sci. USA 1998, 95, 9738-9743. [CrossRef]

66. Demidchik, V. Mechanisms of oxidative stress in plants: From classical chemistry to cell biology. Environ. Exp. Bot. 2015, 109, 212-228. [CrossRef]

67. Kyzek, S.; Holubová, L'.; Medvecká, V.; Zahoranová, A.; Ševčovičová, A.; Gálová, E. Genotoxic effect of low temperature plasma treatment on plant seeds. Toxicol. Lett. 2017, 280S, S119. [CrossRef]

68. Asada, K. The water- water cycle in chloroplasts: Scavenging of active oxygens and dissipation of excess photons. Annu. Rev. Plant. Physiol. Plant Mol. Biol. 1999, 50, 601-639. [CrossRef]

69. Kapoor, D.; Singh, S.; Kumar, V.; Romero, R.; Prasad, R.; Singh, J. Antioxidant enzymes regulation in plants in reference to reactive oxygen species (ROS) and reactive nitrogen species (RNS). Plant. Gene 2019, 19, 100182. [CrossRef]

70. Felzer, B.S.; Cronin, T.; Reilly, J.M.; Melillo, J.M.; Wang, X. Impacts of ozone on trees and crops. C. R. Geosci. 2007, 339, 784-798. [CrossRef]

71. Gill, S.S.; Anjum, N.A.; Gill, R.; Jha, M.; Tuteja, N. DNA damage and repair in plants under ultraviolet and ionizing radiations. Sci. World J. 2015, 2015, 250158. [CrossRef]

72. Corpas, F.J.; Barroso, J.B. Nitric oxide from a "green" perspective. Nitric Oxide Biol. Chem. 2015, 45, 15-19. [CrossRef]

73. Wang, W.; Vinocur, B.; Shoseyov, O.; Altman, A. Role of plant heat-shock proteins and molecular chaperones in the abiotic stress response. Trends Plant. Sci. 2004, 9, 244-252. [CrossRef]

74. McLoughlin, F.; Kim, M.; Marshall, R.S.; Vierstra, R.D.; Vierling, E. HSP101 interacts with the proteasome and promotes the clearance of ubiquitylated protein aggregates. Plant. Physiol. 2019, 180, 1829-1847. [CrossRef]

75. Hong, S.W.; Vierling, E. Hsp101 is necessary for heat tolerance but dispensable for development and germination in the absence of stress. Plant. J. 2001, 27, 25-35. [CrossRef] [PubMed]

76. Nieto-Sotelo, J.; Martínez, L.M.; Ponce, G.; Cassab, G.I.; Alagón, A.; Meeley, R.B.; Ribaut, J.M.; Yang, R. Maize HSP101 plays important roles in both induced and basal thermotolerance and primary root growth. Plant. Cell 2002, 14, 1621-1633. [CrossRef] [PubMed] 
77. Agarwal, M.; Katiyar-Agarwal, S.; Grover, A. Plant Hsp100 proteins: Structure, function and regulation. Plant. Sci. 2002, 163, 397-405. [CrossRef]

78. Kumar, R.; Khungar, L.; Shimphrui, R.; Tiwari, L.D.; Tripathi, G.; Sarkar, N.K.; Agarwal, S.K.; Agarwal, M.; Grover, A. AtHsp101 research sets course of action for the genetic improvement of crops against heat stress. J. Plant Biochem. Biotechnol. 2020, 29, 715-732. [CrossRef]

79. Iranbakhsh, A.; Ardebili, N.O.; Ardebili, Z.O.; Shafaati, M.; Ghoranneviss, M. Non-thermal plasma induced expression of heat shock factor A4A and improved wheat (Triticum aestivum L.) growth and resistance against salt stress. Plasma Chem. Plasma Process. 2018, 38, 29-44. [CrossRef]

80. Černák, M.; Černáková, L'.; Hudec, I.; Kováčik, D.; Zahoranová, A. Diffuse coplanar surface barrier discharge and its applications for in-line processing of low-added-value materials. Eur. Phys. J. Appl. Phys. EDP Sci. 2009, 47, 1-6. [CrossRef]

81. Somogyi, M. Notes on sugar determination. J. Biol. Chem. 1951, 195, 19-23. [CrossRef]

82. Nelson, N. A photometric adaptation of the Somogyi method for the determination of glucose. J. Biol. Chem. 1944, 153, 375-380. [CrossRef]

83. Matušíková, I.; Salaj, J.; Moravčíková, J.; Mlynárová, L.; Nap, J.P.; Libantová, J. Tentacles of in vitro-grown round-leaf sundew (Drosera rotundifolia L.) show induction of chitinase activity upon mimicking the presence of prey. Planta 2005, 222, 1020-1027. [CrossRef]

84. Beauchamp, C.; Fridovich, I. Superoxide dismutase: Improved assay and an assay applicable to acrylamide gels. Anal. Biochem. 1971, 44, 276-287. [CrossRef]

85. Frič, F.; Fuchs, W.H. Veranderungen der Aktivität Einiger Enzyme im Weizenblatt in Abhängigkeit von der Temperaturlabilen Verträglichkeit für Puccinia graminis tritici. J. Phytopathol. 1970, 67, 161-174. [CrossRef]

86. Chance, B.; Maehly, A.C. Assay of catalases and peroxidases. Methods Enzymol. 1955, 2, 764-775. [CrossRef]

87. Collins, A.R. The comet assay for DNA damage and repair: Principles, applications, and limitations. Mol. Biotechnol. 2004, 26, 249-261. [CrossRef]

88. Horváthová, E.; Kozics, K.; Melusová, M.; Galová, E.; Ševčovičová, A.; Kusznierewicz, B.; Chmiel, T.; Slamenová, D. Chromatographic analyses of Lavandula angustifolia and Rosmarinus officinalis extracts and their biological effects in mammalian cells and cell-free systems. Neoplasma 2017, 64, 856-868. [CrossRef] [PubMed]

89. Aranda, P.S.; LaJoie, D.M.; Jorcyk, C.L. Bleach Gel: A simple agarose gel for analyzing RNA quality. Electrophoresis 2012, 33, 366-369. [CrossRef] [PubMed]

90. Taylor, S.C.; Nadeau, K.; Abbasi, M.; Lachance, C.; Nguyen, M.; Fenrich, J. The ultimate qPCR experiment: Producing publication quality, reproducible data the first time. Trends Biotechnol. 2019, 37, 761-774. [CrossRef] 